\title{
Fuel and metabolic scaling during the early life stages of Atlantic cod Gadus morhua
}

\author{
Roderick Nigel Finn ${ }^{1, *}$, Ivar Rønnestad ${ }^{1}$, Terje van der Meeren ${ }^{2}$, Hans Jørgen Fyhn ${ }^{1}$ \\ ${ }^{1}$ Department of Zoology, University of Bergen, Allégt. 41, 5007 Bergen, Norway \\ ${ }^{2}$ Institute of Marine Research, Austevoll Aquaculture Research Station, 5392 Storebø, Norway
}

\begin{abstract}
The simultaneous effect of temperature $\left(5,7,10\right.$ and $\left.13^{\circ} \mathrm{C}\right)$ and light on the rates of oxygen consumption and ammonia excretion of larval and early juvenile Atlantic cod Gadus morhua was examined. Larvae increased their mean dry body mass by 2000 times within $48 \mathrm{~d}$. Instantaneous growth rate exceeded $30 \% \mathrm{~d}^{-1}$ towards the end of the study period, and proportionality of growth followed a triphasic pattern, during which body water content significantly declined but no inflection could be detected in the metabolic exponents. Data were rigorously tested via Model-I (least squares) and Model-II (geometric mean) regression techniques, and the aerobic metabolic rate was found to scale allometrically with both dry and wet body mass. The metabolic exponent was not affected by increasing temperature, but was significantly decreased by the presence of light $(b=0.88$ to 0.89 for light-adapted larvae; $b=0.90$ to 0.91 for dark-adapted larvae). The effect of light on small larvae (4 to $7 \mathrm{~mm}$ standard length, SL) caused a 30 to $40 \%$ increase in metabolic rate, while no effect was observed in larger juveniles (40 to $60 \mathrm{~mm} \mathrm{SL}$ ). Acute temperature acclimation of Atlantic cod of 4 to $60 \mathrm{~mm}$ SL (0.04 to $350 \mathrm{mg}$ dry mass) demonstrated normal thermal sensitivity with $Q_{10}$ values of 2.4 for dark-adapted larvae and 2.6 for light-adapted larvae. Rates of ammonia excretion also scaled allometrically with wet and dry body mass and showed greater variability in dark-adapted compared to light-adapted larvae. Comparison of the molar rates of ammonia excretion and oxygen consumption revealed that Atlantic cod larvae have a high reliance on amino acids as fuel for energy dissipation. With lipids as the assumed co-substrate, amino acids were estimated to account for 70 to $95 \%$ of total substrate oxidation for larvae up to $7 \mathrm{~mm}$ SL (first 3 to $4 \mathrm{wk}$ of post-hatch development). Beyond $7 \mathrm{~mm}$ $\mathrm{SL}$, the reliance on amino acids as fuel began to decline, but even in juveniles of 40 to $60 \mathrm{~mm} \mathrm{SL}$, amino acids still represented the dominant source of fuel. For juveniles of between 10 and $20 \mathrm{~mm} \mathrm{SL}$, both the rates of oxygen consumption and ammonia excretion remained unaffected by the presence of food in the gut. For short-term fasted juveniles (35 to $60 \mathrm{~mm} \mathrm{SL}$ ), however, a substantial decline in the rate of ammonia excretion was observed. This indicates that during short-term fasting (8 to $12 \mathrm{~h}$ ) early juvenile Atlantic cod conserve amino acids, rather than funneling them into the tricarboxylic acid cycle.
\end{abstract}

KEY WORDS: Scaling $\cdot$ Metabolism $\cdot$ Fuel preference $\cdot$ Free amino acid $\cdot Q_{10} \cdot$ Temperature $\cdot$ Cod larvae Resale or republication not permitted without written consent of the publisher

\section{INTRODUCTION}

There is a large volume of literature relating the metabolic rate of animals to their body mass. For vertebrates, the majority of studies have examined these

\footnotetext{
*Email: nigel.finn@zoo.uib.no
}

relationships for reptiles, birds and mammals (Hemmingsen 1950, 1960, Zeuthen 1953, 1970, Kleiber 1975, Peters 1983, Schmidt-Nielsen 1984, LaBarbera 1989). The generally accepted, though much debated (Heusner 1982, Feldman \& McMahon 1983, Wieser 1984, Riisgård 1998, Witting 1998, Darveau et al. 2002) exponent relating metabolic rate to body mass throughout the animal kingdom is 0.75 (Kleiber 1932, 
1975). For the juvenile and adult stages of fishes, however, a general exponent of 0.8 has been proposed (Winberg 1956, Wieser 1995, Clarke \& Johnston 1999). Giguère et al. (1988) have proposed that the metabolic rates of larval fishes scale isometrically with increasing body mass. Post \& Lee (1996) also argue for isometric or near-isometric scaling of routine metabolic rate, and they suggest a biphasic ontogeny of metabolism in larval teleosts that is correlated with changing surfaceto-volume ratios. Bochdansky \& Leggett (2001), however, argue that metabolic scaling of fish larvae follows a curvilinear relationship with increasing body size. Both Giguère et al. (1988) and Bochdansky \& Leggett (2001) base their general notions upon interspecific comparisons. Indeed this approach forms the basis of theories that seek to explain the cause of quarterpower scaling in all living organisms (West et al. 1997, 1999, 2001, 2002, Banavar et al. 1999, Enquist et al. 1999, Gillooly et al. 2001, 2002). According to Wieser (1984), however, and more recently to Goolish (1995), Post \& Lee (1996) and Darveau et al. (2002), it is important to distinguish between, on the one hand, the intraspecific ontogeny and control of metabolism and, on the other, the interspecific relations of metabolic rate, since failure to do so can confuse the underlying biology of the mass exponent of energy metabolism.

Not all investigators have found an isometric relationship of metabolic rate and body size for the larval stages of fishes (Gruber \& Wieser 1983, Wieser \& Forstner 1986, De Silva et al. 1986, Bishop \& Torres 1999). Moreover, earlier studies of Atlantic cod Gadus morhua larvae (Laurence 1978, Serigstad 1987a) have reported metabolic exponents not only of less than unity but of similar magnitude to the juvenile and adult stages studied (Sundnes 1957, Saunders 1963, Edwards et al. 1972). These earlier works, with the exception of Edwards et al. (1972) and Serigstad (1987a), used chemical or manometric techniques to estimate the rate of oxygen consumption. The data of Laurence (1978), remodelled by Laurence (1985), continue to be cited as the basis for models of the metabolism and growth of larval cod (Liesing \& Franks 1999, 2000, Buckley et al. 2000). The original data of Laurence (1978) were obtained using a Warburg manometer with agitation during experimentation. As noted by Finn (1994), the manometric method used by Laurence (1973) on larval tautog gave estimates of oxygen consumption that were 4 to 5 times higher than for larvae of other species of fish. A similar observation was also indirectly made by Bochdansky \& Legget (2001) for Atlantic cod, when they removed Laurence's (1978) data from their analyses. Further, the currently published models for Atlantic cod are based on a $Q_{10}$ temperature coefficient of 1.07 (Liesing \& Franks 1999). Such a value is exceptionally low for fish larvae (Rombough 1988) and requires confirmation.
The Atlantic cod is arguably one of the commercial world's most important species of fish (Kurlansky 1998). As a consequence considerable attention has been placed on its metabolic physiology in order to better understand the life history of this species. Previous studies of juvenile and adult stages of Atlantic cod have investigated the influence of hypoxia, swimming performance, temperature, salinity, and food on the metabolic rate (Soofiani \& Hawkins 1982, Soofiani \& Priede 1985, Schurmann \& Steffensen 1992, 1994, 1997, Bushnell et al. 1994, Nelsen et al. 1996, Steffensen et al. 1994, Tang et al. 1994, Claireaux et al. 1995a,b, 2000, Blaikie \& Kerr 1996, Dutil et al. 1997, Reidy et al. 2000). Surprisingly, however, many of these extrinsic and intrinsic factors have yet to be examined for the critically important larval stages. Apart from the studies of Laurence (1978) and Serigstad (1987a), most metabolic studies during the early life stages of Atlantic cod have been confined to the yolk-sac or first-feeding stages (Davenport \& Lønning 1980, Davenport et al. 1983, Solberg \& Tilseth 1984, 1987, Serigstad 1986, 1987b, Fyhn \& Serigstad 1987, Vigrestad 1993, Finn et al. 1995a,b). More recently, Hunt von Herbing \& Boutelier (1996) and Hunt von Herbing et al. (2001) were able to correlate the metabolic rate of larval Atlantic cod to different activity events, while Hunt von Herbing et al. $(1996 a-c)$ have staged the larvae and early juveniles and provided detailed descriptions of the ontogony of cranial morphology in relation to expected respiratory function.

An important influence on the metabolic rate of fish larvae in the euphotic zone is the presence or absence of light. This especially applies to visual-feeding larvae (Skiftesvik 1992, Cerqueira \& Brugger 2001, Downing \& Litvak 2001, Utne-Palm \& Stiansen 2002). Recent studies have described the advantage of natural light for the growth of Arcto-Norwegian and coastal Atlantic cod (van der Meeren \& Jørstad 2001), while other studies have examined the effect of light on the metabolic rate of other larval fishes (Finn et al. 1995c,d, Porter 2001). Apart from the yolk-sac stage studies of Solberg \& Tilseth (1984), Serigstad (1987a) and Finn et al. (1995a), no information seems to exist on the important influence of light on the metabolic rate of the early life stages of Atlantic cod. Similarly, the substrate used to fuel metabolism has received little attention in the literature. The only studies published for Atlantic cod larvae are for the cleidoic phase of yolk resorption (Fyhn \& Serigstad 1987, Finn et al. 1995a). In the latter study, it was argued that Atlantic cod larvae have a high reliance of amino-acid catabolism as the major foundation of their energy dissipation. At present, however, we remain ignorant of the potential fuel of exogenously feeding larvae. 
The initial small size and the rapid growth of Atlantic cod larvae (van der Meeren et al. 1994, Otterlei 2000) make them excellent models for studying the metabolic implications of scaling. Hence, this paper examines the influence of temperature and light on fuel preference and metabolic scaling from first-feeding to beyond metamorphosis of Atlantic cod. The data are intended as an aid to the construction of more accurate models for this important species.

\section{MATERIALS AND METHODS}

Two main series of Atlantic cod Gadus morhua larvae were followed, each originating from batches of naturally fertilised eggs. Eggs were incubated at 7 to $8^{\circ} \mathrm{C}$ and transferred to rearing systems on the fourth day post hatching. Larvae were reared under ambient photoperiod (April to June: $60^{\circ} \mathrm{N}, 5^{\circ} \mathrm{E}$ ) and temperature in black-plastic mesocosms $\left(5.2 \mathrm{~m}^{3}\right)$ on the west coast of Norway near Bergen. Larvae were fed according the feeding rations outlined by van der Meeren et al. (1994) by filtering relevant size fractions of natural zooplankton (mainly Eurytemora affinis copepods) into the mesocosms for the duration of the experimental investigation. Prior to respirometry, larvae were transferred to the laboratory and placed in clean $(0.2 \mu \mathrm{m}$ filtered) seawater (32 to $33 \%$ ) at the relevant experimental temperature. To examine the effect of acute temperature changes on the routine rates of oxygen consumption $\left(\dot{V}_{\mathrm{O}_{2}}\right)$ and ammonia excretion $\left(\dot{V}_{\mathrm{NH}_{3}}\right)$, larvae were fasted ( 8 to $12 \mathrm{~h}$, depending on size) while acclimating to the experimental temperatures of 7,10 and $13{ }^{\circ} \mathrm{C}$ with maximum deviations of $\pm 0.02^{\circ} \mathrm{C}$ (Series1 experiments). Temperature maintenance in the laboratory was achieved via water baths using an arrangement of antagonistic thermostats and coolers (Heto), and monitored using a Squirrel (type SQ8-4U, Grant Instruments) data logger. During temperature acclimation, larvae were exposed to ambient light in the laboratory using Luma long-life, standard, colour, fluorescent lamps (36 W/L-73, emitting 70\% daylight at $3000 \mathrm{~K})$ which were suspended over the acclimation tanks. Irradiance was determined to be $\sim 50 \mu \mathrm{E} \mathrm{s}^{-1} \mathrm{~m}^{-2}$ at the water surface using a $180^{\circ}$ LI-192SA cosinecorrected underwater quantum sensor attached to a Li-Cor LI 1000 light meter (Li-Cor Environmental). All respiratory measurements were conducted on individual larvae or juveniles. Small larvae were transferred by pipette, while large juveniles were caught by hand in the acclimation vessels (to reduce inclusion of acclimation water) and inserted into the closed respirometers (glass Quickfit FR:S vials) of varying sizes (40 to $500 \mathrm{ml}$ calibrated volume) in an ordered series of 2 blanks, 8 experimental, 2 blanks, 8 experimental, and 2 blanks, such that 16 experimental respirometers could be compared to 6 blank respirometers. All respirometers had previously been filled with aerated clean seawater simultaneously acclimated at each experimental temperature. In addition, $\sim 1$ to $2 \mathrm{ml}$ of larval acclimation water was injected into the blank respirometers in order to compensate for the small amount of water associated with the larvae. This procedure was used to allow correction for drift in either the $\mathrm{pO}_{2}$ or $\left[\mathrm{NH}_{3}\right]$, which, if found, was assumed to be linear between blanks. The respirometers were then placed on racks in the thermostat-controlled water bath, where they were exposed to light (10 to $25 \mu \mathrm{E}$ $\mathrm{s}^{-1} \mathrm{~m}^{-2}$ at the respirometer surface). This procedure was repeated for a second set of 16 experimental and 6 blank respirometers, which were subsequently wrapped in thick black plastic (light transmittance measured to $0 \mu \mathrm{E} \mathrm{s}^{-1} \mathrm{~m}^{-2}$ ) and placed together with the first set of respirometers.

To examine the effect ingested food on the $\dot{V}_{\mathrm{O}_{2}}$ and $\dot{V}_{\mathrm{NH}_{3}}$ (Series-2 experiments), larvae and early juveniles were transferred from their rearing mesocosms to clean filtered seawater at $10^{\circ} \mathrm{C}, 32$ to $33 \%$ as described for the Series-1 experiments. After $1 \mathrm{~h}$ of temperature acclimation, individual larvae were inspected under a binocular microscope to ensure the guts contained food organisms prior to inclusion in the respirometers. These experiments were compared to larvae that had been fasted, and acclimated for 8 to $12 \mathrm{~h}$, and that had had no food organisms in the gut during the respirometry. The fed and fasted larvae were examined in the same manner as described for the Series-1 experiments, such that on each Day 16 fed larvae in light and 16 fed larvae in darkness were compared to 16 fasted larvae in light and 16 fasted larvae in darkness at $10^{\circ} \mathrm{C}$.

To specifically examine the very earliest phases following the resorption of yolk, a third series of experiments (Series 3) was conducted on larvae at the firstfeeding stage. To ensure the correct size range for the first-feeding larvae, eggs stripped and artificially fertilised from 14 female Atlantic cod were incubated in clean seawater $(34.5 \%)$ at $5^{\circ} \mathrm{C}$ under a $12: 12 \mathrm{~h}$ light: dark photoperiod. Yolk resorption occurred on Day 26 post-fertilisation. On this day, 67 measurements were conducted on groups of 4 to 5 pooled larvae from the different females. Larval rates of $\dot{V}_{\mathrm{O}_{2}}$ and $\dot{V}_{\mathrm{NH}_{3}}$ at $5^{\circ} \mathrm{C}$ exposed to light (10 to $25 \mu \mathrm{E} \mathrm{s}^{-1} \mathrm{~m}^{-2}$ at the respirometer surface) were determined.

The $\dot{V}_{\mathrm{O}_{2}}$ was measured by polarographic detection of the oxygen tension (Radiometer E5046 electrode in conjunction with a pH M73 blood-gas analyser) and calculated as the difference between blank and experimental respirometers. The incubation times of the largest juveniles were carefully timed so that the $\mathrm{pO}_{2}$ did not fall below $6.67 \mathrm{kPa}(50 \mathrm{~mm} \mathrm{Hg})$, the critical 
level at which respiration of Atlantic cod larvae becomes dependent upon available oxygen (Serigstad 1987a). $\dot{V}_{\mathrm{O}_{2}}$ is expressed as nmol ind.$^{-1} \mathrm{~h}^{-1}$ or as a massspecific rate $\left(\dot{V}_{\mathrm{O}_{2} \mathrm{w}}\right)$ as $\mu \mathrm{mol} \mathrm{g} \mathrm{g}^{-1} \mathrm{~h}^{-1}$. The molar $\dot{V}_{\mathrm{O}_{2}}$ can be converted to the power rate of heat dissipation using a general oxycaloric coefficient of $450 \mathrm{~kJ} \mathrm{~mol}^{-1}$ $\mathrm{O}_{2}$ (Gnaiger \& Kemp 1990). Since the larvae were not hindered in any way within the respirometers, their $\dot{V}_{\mathrm{O}_{2}}$ was assumed to represent the routine rate under the given experimental conditions. The polarographic oxygen sensor was calibrated prior to and after each ordered set of blanks and 8 experimental respirometers, and any drift occurring between calibrations was assumed to be linear. In essence this was essentially every hour, and the maximum recorded hourly drift for any of the experiments was $0.13 \mathrm{kPa}(\sim 1 \mathrm{~mm} \mathrm{Hg})$. The solubility of oxygen in seawater at each experimental temperature was calculated after Green \& Carrit (1967) and Forstner \& Gnaiger (1983). The $\dot{V}_{\mathrm{NH}_{3}}$ was determined by sampling $1 \mathrm{ml}$ of the respirometer water (4 replicates) and analysing the $\left[\mathrm{NH}_{3}\right]$ according to the procedure of Bower \& Holm-Hansen (1980). The molar ratio of $\dot{V}_{\mathrm{NH}_{3}}$ to $\dot{V}_{\mathrm{O}_{2}}$ was used to calculate the apparent nitrogen quotient $(N Q)$, which, depending on the cosubstrate catabolised, gives an estimate of the mass fraction of amino acids used as fuel (Gnaiger 1983). The calculation assumes that metabolism is fully aerobic and dissipative, as found for turbot (Finn et al. 1995c), but does not account for other forms of excretory nitrogen. Further, since all measurements were conducted on growing, but non-exercising, individuals, the apparent $N Q$ s are considered to be a minimum estimate of the relative contribution of amino acids as metabolic fuel.

Following the respiratory measurements, each larva was measured for linear proportions, standard length (SL), and myotome height (MH), as shown in Fig. 2, using a binocular microscope at 6 to $50 \times$ magnification for the smaller larvae and a Vernier gauge for the SLs of the larger juveniles. Each larva or juvenile was killed (blow to the head), briefly rinsed in distilled water and carefully blotted with soft tissue paper (Kimwipes $\left.{ }^{\circledR}\right)$ to remove excess water; it was then placed in preweighed cryotubes (Nunc) for estimation of the wet mass (Sartorius top balance accurate to $\pm 0.1 \mathrm{mg}$ ). Larvae were then frozen at $-80^{\circ} \mathrm{C}$, lyophilised and weighed on a Cahn 25 Automatic electrobalance (accurate to $\pm 1 \mu \mathrm{g}$ ) for estimation of the dry mass. The water content was calculated from the difference between the wet and dry masses.

Data analyses were performed on ln-transformed data, where equations are of the allometric form $y=a x^{b}$, and on untransformed data, where equations are of the form $y=a+b x$. These structural models were examined using both Model-I (least-squares) and Model-II (geometric- mean) regression techniques and statistically tested via analysis of covariance (ANCOVA) according to the recommendations of Sokal \& Rohlf (2000). Significant differences between regressions were examined by Gabriel's approximate $T^{\prime}$ and GT2 minimum significant difference (MSD) methods outlined by Rohlf \& Sokal (1995) and Sokal \& Rohlf (2000). Significant differences were only acknowledged if both the MSD and the $95 \%$ confidence intervals of the Model-I and Model-II regressions did not overlap.

Interpretations regarding allometric scaling of metabolic rates related to body mass were based on the regression coefficient's significant departure from unity, and for the allometric scaling of body proportions when the regression coefficient significantly departed from 3. This latter interpretation is based on the assumption that body mass reflects the larval volume, which, for isometric growth, varies as the cube of any given linear dimension, and the $y$-intercept passes through zero (Schmidt-Nielsen 1984, Packard \& Boardman 1988). Instantaneous growth rate, $G\left(\% \mathrm{~d}^{-1}\right)$, was calculated according to the recommendations of Ricker (1958) as $G=\left(\mathrm{e}^{g}-1\right) \times 100 ; g$ is the instantaneous growth coefficient calculated as $\left[\ln \left(\mathrm{d} M_{t_{2}}\right)-\right.$ $\left.\ln \left(\mathrm{d} M_{t_{1}}\right)\right] / \Delta t$, where $\mathrm{d} M_{t_{2}}$ and $\mathrm{d} M_{t_{1}}$ are the mean dry masses at times $t_{2}$ and $t_{1}$, respectively.

The influence of temperature was assessed via the van't Hoff equation for $Q_{10}$ (Eckert 1997). Since the scaling of metabolic rate proved to be allometric, $Q_{10}$ values for individuals of any given size were calculated for temperature intervals of 7 to $10^{\circ} \mathrm{C}$ and 10 to $13^{\circ} \mathrm{C}$ using the allometric equations given in Table 2. Since temperature was found not to significantly $(p>0.05)$ affect the metabolic coefficients ( $b$ and $v$ ) of either light- or dark-adapted larvae, mean regression coefficients of $b=0.8851$ for light-adapted individuals and $b=0.9124$ for dark-adapted individuals were used for calculating the $Q_{10}$ values.

\section{RESULTS}

Following the onset of exogenous feeding, the closely monitored larvae of Series 1, which had hatched $14 \mathrm{~d}$ post-fertilisation, showed an accelerating growth rate over the $48 \mathrm{~d}$ of study (Fig. 1). The instantaneous growth rate of Series-1 larvae increased from $7 \% \mathrm{~d}^{-1}$ at the lower temperatures of 7 to $8^{\circ} \mathrm{C}$ in April, to more than $30 \% \mathrm{~d}^{-1}$ when experiencing the higher temperatures of 14 to $17^{\circ} \mathrm{C}$ in June. The larvae and juveniles of Series 2 showed growth rates of about $22 \% \mathrm{~d}^{-1}$ between 60 and $80 \mathrm{~d}$ post-fertilisation when rearing temperatures increased from 11 to $18^{\circ} \mathrm{C}$ (temperature data not shown in Fig. 1). This temperature increase was experienced by Series-1 larvae between Days 35 


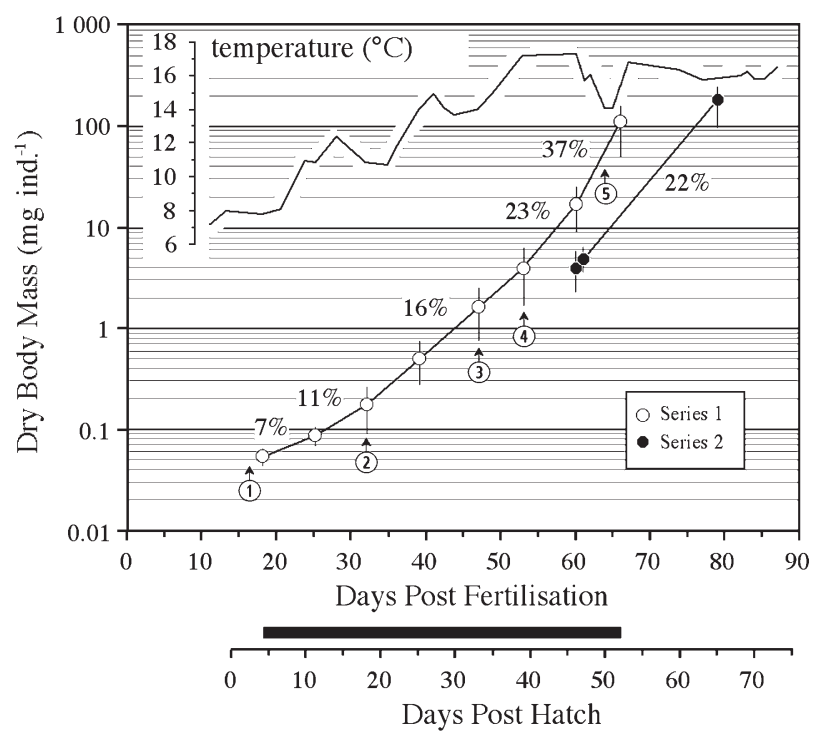

Fig. 1. Gadus morhua. Growth (dry mass) of larvae and early juveniles of Atlantic cod reared under natural conditions (April-June; $60^{\circ} \mathrm{N}, 5^{\circ} \mathrm{E}$ ) in a mesocosm and fed natural copepods ad libitum. The recorded temperature for Series-1 experiments is shown above the growth curve. The temperature data for Series 2 is not shown. Data points represent mean \pm SD for an N of 42-48 (Series 1) and 44-70 (Series 2). The instantaneous growth rates $\left(\% \mathrm{~d}^{-1}\right)$ shown above the growth curve were determined from exponential curves fitted to the data of ranges: $18-25,25-32,32-53,53-60$, and 60-66 d post fertilisation, respectively. The circled numbers below the data points represent the 5 larvae depicted in Fig. 2. The shaded bar above the days post-hatch scale represents the $48 \mathrm{~d}$ study period of Series-1 experiments

and 50 post-fertilisation when their instantaneous growth rate was 16 to $23 \% \mathrm{~d}^{-1}$. Both series therefore had similar growth rates under increasing temperature conditions. The more complete data set of Series 1 illustrate that cod larvae, given the right conditions, are capable of increasing their mean dry body mass by 2000 times in just $48 \mathrm{~d}$ (0.055 to $110 \mathrm{mg}$ ind.$\left.^{-1}\right)$.

During the course of this rapid growth, the relationship between body mass, MH and SL altered and could be separated into 3 distinct phases (Fig. 2). Following the onset of exogenous feeding and until a SL of $7 \mathrm{~mm}$, larvae grew isometrically $(b \approx 3)$ with respect to increasing wet and dry mass as functions of SL (Eqs. $1 \& 4$; Table 1). Between an SL of 7 to $12 \mathrm{~mm}$, larval growth was allometric ( $b \approx 4$, Eqs. $2 \& 5$; Table 1 ), and between 12 and $60 \mathrm{~mm} \mathrm{SL}$, growth had become near-isometric ( $b=3.2$ to 3.4 , Eqs. $3 \& 6$; Table 1 ). These 3 phases of growth were also reflected in the changing $\mathrm{MH}$, although at each phase the relationship between $\mathrm{MH}$ and SL remained allometric. During the third phase of growth (12 to $60 \mathrm{~mm}$ ) the relative body-water content declined significantly ( $p<0.001$, Fig. 3 ). This was true for both Series-1 and Series-2 juveniles, although the decline in the latter series was greatest.

Despite the tri-phasic pattern of growth and changing body proportions, no inflection could be found in the metabolic scaling of $\dot{V}_{\mathrm{O}_{2}}$ as a function of body mass at any temperature, whether in darkness or exposed to light (Figs. 4 \& 5). Furthermore the aerobic metabolic rate scaled allometrically with respect to body mass under all experimental conditions (Eqs. 1-6 \& 13-18; Table 2). Rigorous data analysis via the stepwise removal of data points from larger larvae down to $0.1 \mathrm{mg}$ ind.$^{-1}$ dry mass did not yield isometric values for any of the regression coefficients for either Model-I or Model-II regression techniques ( $b$ and $v<1, \mathrm{p}<0.05$ ). For larvae between 0.04 and $0.1 \mathrm{mg}$ ind. ${ }^{-1}$ dry mass, the variance increased considerably and regression coefficients were not significantly different from unity. Specific analysis of the $\dot{V}_{\mathrm{O}_{2}}$ of the 14 groups of first-

Table 1. Gadus morhua. Biometric scaling constants and statistics for power equations of the form $y=a x^{b}$, Model-I least-squares regression and $y=u x^{v}$, Model-II geometric-mean regression. Natural-logarithm-transformed data are modelled for Series-1 larvae. Regression constants are valid for the given size ranges. 95\% confidence intervals (CI) and $\mathrm{r}^{2}$ values are relevant for both Model-I and Model-II regression coefficients ( $b$ and v). dM: dry mass; SL: standard length; wM: wet mass; MH: myotome height

\begin{tabular}{|c|c|c|c|c|c|c|c|c|}
\hline \multirow[t]{2}{*}{ Equation } & \multirow{2}{*}{$\begin{array}{l}\text { Size range } \\
\quad(\mathrm{mm})\end{array}$} & \multirow[b]{2}{*}{$\mathrm{N}$} & \multicolumn{2}{|c|}{$\longrightarrow$ Model I } & \multicolumn{2}{|c|}{$\longrightarrow$ Model II $\longrightarrow$} & \multirow{2}{*}{$\begin{array}{c}95 \% \\
\text { CI }\end{array}$} & \multirow[t]{2}{*}{$r^{2}$} \\
\hline & & & a & $b$ & $u$ & $V$ & & \\
\hline \multicolumn{9}{|c|}{ dM (mg) vs SL (mm) } \\
\hline (1) & $4-7$ & 115 & $4.12 \times 10^{-4}$ & 3.109 & $3.17 \times 10^{-4}$ & 3.262 & 0.184 & 0.908 \\
\hline (2) & $7-12$ & 80 & $6.40 \times 10^{-5}$ & 4.129 & $5.13 \times 10^{-5}$ & 4.229 & 0.206 & 0.953 \\
\hline (3) & $12-60$ & 127 & $3.59 \times 10^{-4}$ & 3.406 & $3.52 \times 10^{-4}$ & 3.413 & 0.038 & 0.996 \\
\hline \multicolumn{9}{|c|}{ wM (mg) vs SL (mm) } \\
\hline (4) & $4-7$ & 123 & $3.84 \times 10^{-3}$ & 2.924 & $2.50 \times 10^{-3}$ & 3.177 & 0.224 & 0.847 \\
\hline (5) & $7-12$ & 87 & $4.60 \times 10^{-4}$ & 4.079 & $3.76 \times 10^{-4}$ & 4.169 & 0.187 & 0.957 \\
\hline (6) & $12-60$ & 140 & $3.59 \times 10^{-3}$ & 3.237 & $3.54 \times 10^{-3}$ & 3.242 & 0.029 & 0.997 \\
\hline \multicolumn{9}{|c|}{ MH (mm) vs SL (mm) } \\
\hline (7) & $4-7$ & 123 & $3.42 \times 10^{-2}$ & 1.294 & $2.97 \times 10^{-2}$ & 1.377 & 0.085 & 0.883 \\
\hline (8) & $7-12$ & 87 & $6.04 \times 10^{-3}$ & 2.192 & $5.45 \times 10^{-3}$ & 2.238 & 0.097 & 0.959 \\
\hline (9) & $12-60$ & 229 & $3.28 \times 10^{-2}$ & 1.446 & $3.15 \times 10^{-2}$ & 1.460 & 0.027 & 0.981 \\
\hline
\end{tabular}




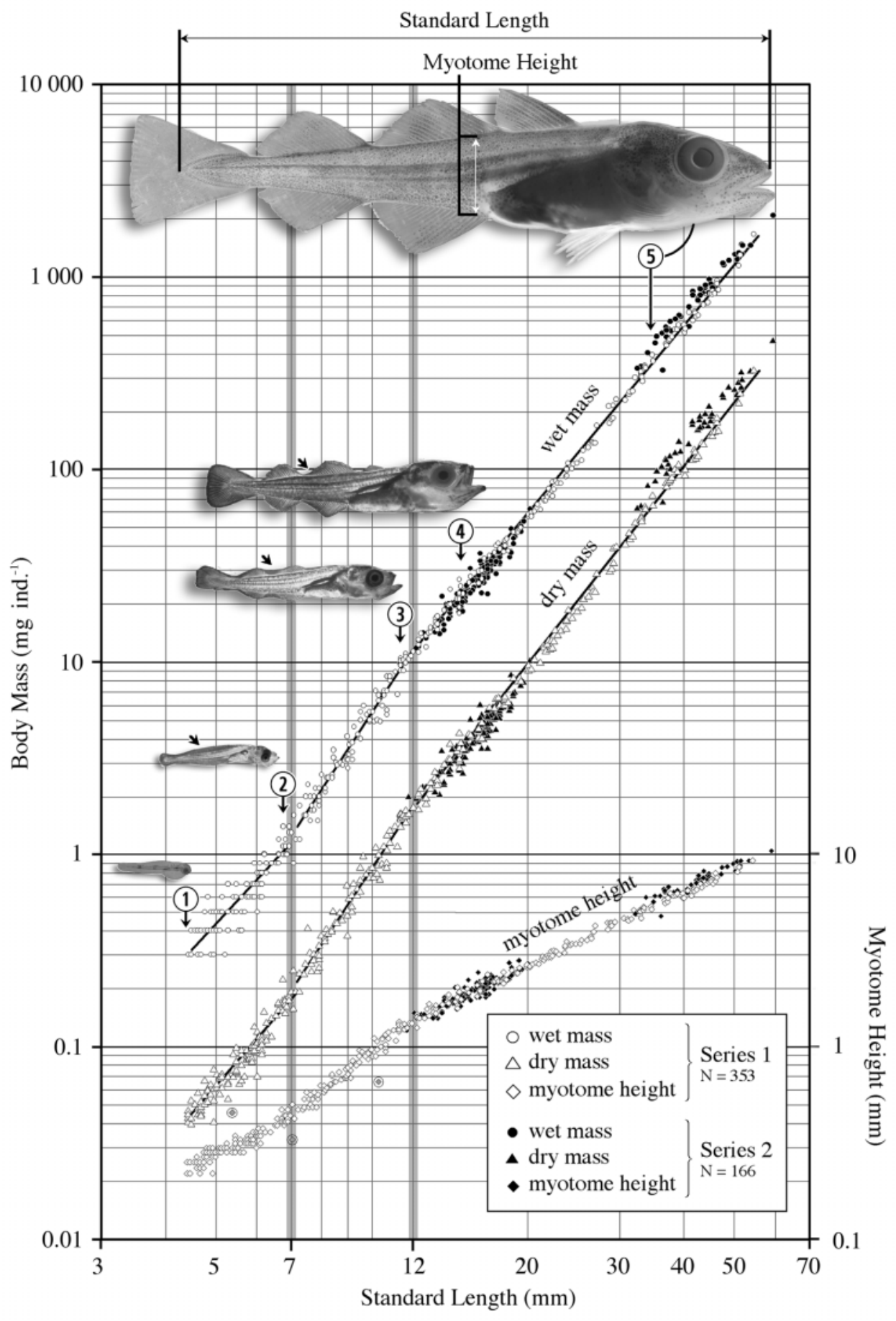

Fig. 2. Gadus morhua. Scaling of wet body mass, dry body mass and myotome height in relation to standard length (SL) of larvae and early juvenile Atlantic cod reared under natural conditions (see 'Materials and methods'). Each point represents an individual larva. The natural-logarithmtransformed data of Series 1 are modelled by simple leastsquares (Model I) and geometric-mean (Model II) regression of the form $\ln y=\ln a+b \ln x$. These curves are shown fitted in the form of power equations ( $y=$ $a x^{b}$ ) to the original data of Series 1 on double log-axes. Equations are given in Table 1. Three phases of changing body proportions were found: larvae between 4 and $7 \mathrm{~mm}$ grew isometrically $(b \approx 3)$, larvae between 7 and $12 \mathrm{~mm}$ grew allometrically $(b \approx 4)$, while larvae between 7 and $12 \mathrm{~mm}$ grew near isometrically $(b=3.2-3.4)$. Photographs of representative larvae are shown to scale, and placed in relation to the $x$-axis with SLs as follows: (1) 4.3 , (2) 6.8 , (3) 11.4 , (4) 14.8 , (5) $35.4 \mathrm{~mm}$. Note that the $x$-axis is logarithmic. The 3 scaling phases could be recognised by the regression of the fin margin (45 $5^{\circ}$ black arrows on larva (2), (3) and (4) and appearance of fin rays

feeding larvae from Series 3 at $5^{\circ} \mathrm{C}$ (dry mass: 0.04 to $0.07 \mathrm{mg}$ ind. ${ }^{-1}$ ) also could not demonstrate $b$ values with significant departure from unity (Fig. 6). Over these short size ranges, however, data variance increased considerably, as reflected in the $r^{2}$ value (Eq. 33; Table 2) and the 2 regression techniques showed highly divergent results: Model I: $b=0.990 \pm$ 0.332; Model II: $v=1.648 \pm 0.332$ (Table 2).
The simultaneous effect of light and temperature (Series-1 experiments), revealed discrete metabolic responses with increasing body mass (Fig. 7). The data for $\dot{V}_{\mathrm{O}_{2}}$ of Series-1 larvae exposed to light and darkness revealed that temperature did not significantly affect the slopes of the curves, but caused a parallel upward shift with increasing temperature. Thus, to evaluate the effect of light and temperature, mean regression 


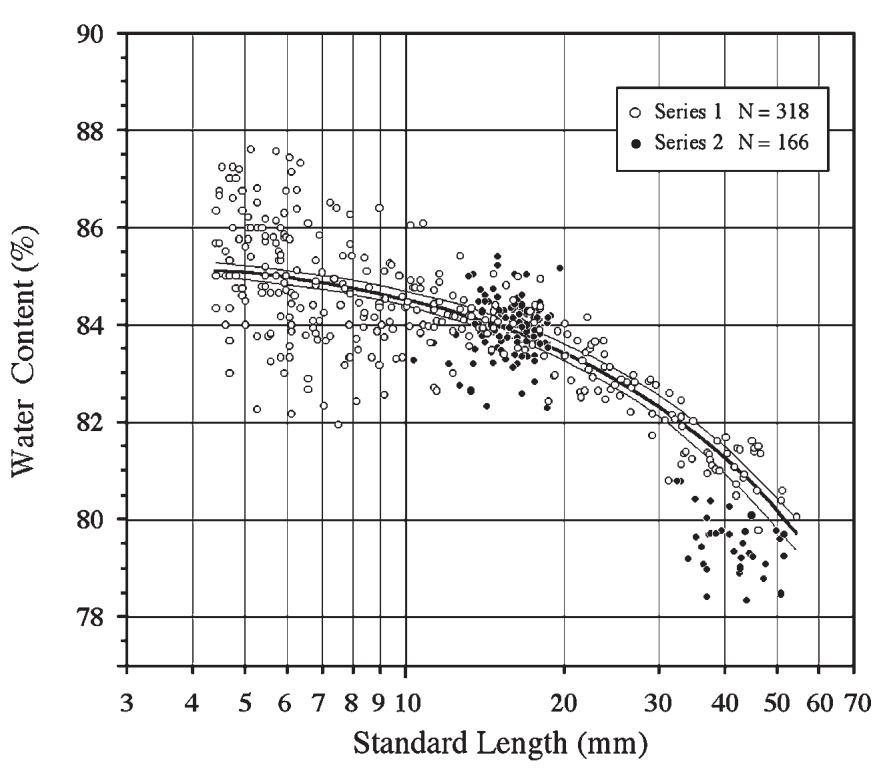

Fig. 3. Gadus morhua. Water content (\% of wet mass) in relation to SL of larvae and early juvenile Atlantic cod. The curve is fitted $( \pm 95 \% \mathrm{CI})$ to the untransformed data of Series 1 by Model-I least-squares linear regression

coefficients ( $b$ and $v$ ) of 0.8851 , for larvae exposed to light, and 0.9124, for larvae in darkness were used for further computation. Light was most influential on small larvae, where mass-specific aerobic metabolic rates increased by factors of 1.3 to 1.4 times the rate in darkness at any given temperature. The stimulatory effect of light gradually declined, however, until no significant effect could be detected in the largest juveniles, as reflected in the shallower slope of the $\dot{V}_{\mathrm{O}_{2}}$ of the light-adapted individuals. The $Q_{10}$ estimates of the effect of temperature on routine metabolic rate were calculated for mean metabolic exponents of light- and dark-adapted larvae. The $Q_{10}$ values were found to decrease with increasing temperature such that values for light-exposed larvae ranged from 2.53 to 2.61, with a mean of 2.57 , while $Q_{10}$ values for larvae in darkness ranged from 2.36 to 2.46 , with a mean of 2.40 .

Allometric scaling relationships were also established for the larval rates of ammonia excretion $\left(\dot{V}_{\mathrm{NH}_{3}}\right)$ versus dry and wet mass in both light and darkness at the 3 experimental temperatures (Figs. 4 \& 5). The variablity of the $\dot{V}_{\mathrm{NH}_{3}}$ data were greater than for $\dot{V}_{\mathrm{O}_{2}}$ particularly for the dark-adapted larvae. Regression analysis and ANCOVA revealed that the slopes did not differ $(p>0.05)$ over the full range of dry and wet masses of light-adapted larvae (Eqs. 7-9 and 19-21, Table 2). This also proved true for the dark-adapted larvae, but only for larvae with dry masses falling in the range of 0.08 to $100 \mathrm{mg}$ ind..$^{-1}$ and wet masses between 0.3 and $530 \mathrm{mg}$ ind. $^{-1}$ (Eqs. 10-12 \& 22-24; Table 2). Specific analysis of the $\dot{V}_{\mathrm{NH}_{3}}$ of the 14 groups of first-feeding larvae from Series 3 at $5^{\circ} \mathrm{C}$ (dry mass: 0.04 to $0.07 \mathrm{mg}$ ind. ${ }^{-1}$ ) showed significant differences between the regression coefficients of Model-I and Model-II methods. The regression coefficient of Model I did not reveal a significant departure from isometric
Fig. 4. Gadus morhua. Routine rate $\left(\mathrm{nmol}\right.$ ind. $\left.{ }^{-1} \mathrm{~h}^{-1}\right)$ of oxygen uptake $\left(\dot{V}_{\mathrm{O}_{2}}\right)$ and ammonia excretion $\left(\dot{V}_{\mathrm{NH}_{3}}\right)$ related to dry mass of individual short-term-fasted larvae and early juvenile Atlantic cod (Series 1) at 3 temperatures exposed to light of $10-25 \mu \mathrm{E} \mathrm{s}{ }^{-1}$ $\mathrm{m}^{-2}$ at the respirometer surface. The fasting period varied from 8 to $12 \mathrm{~h}$ depending on larval size. The curves are modelled as described for Fig. 2 and shown fitted to untransformed data on doublelogarithmic axes

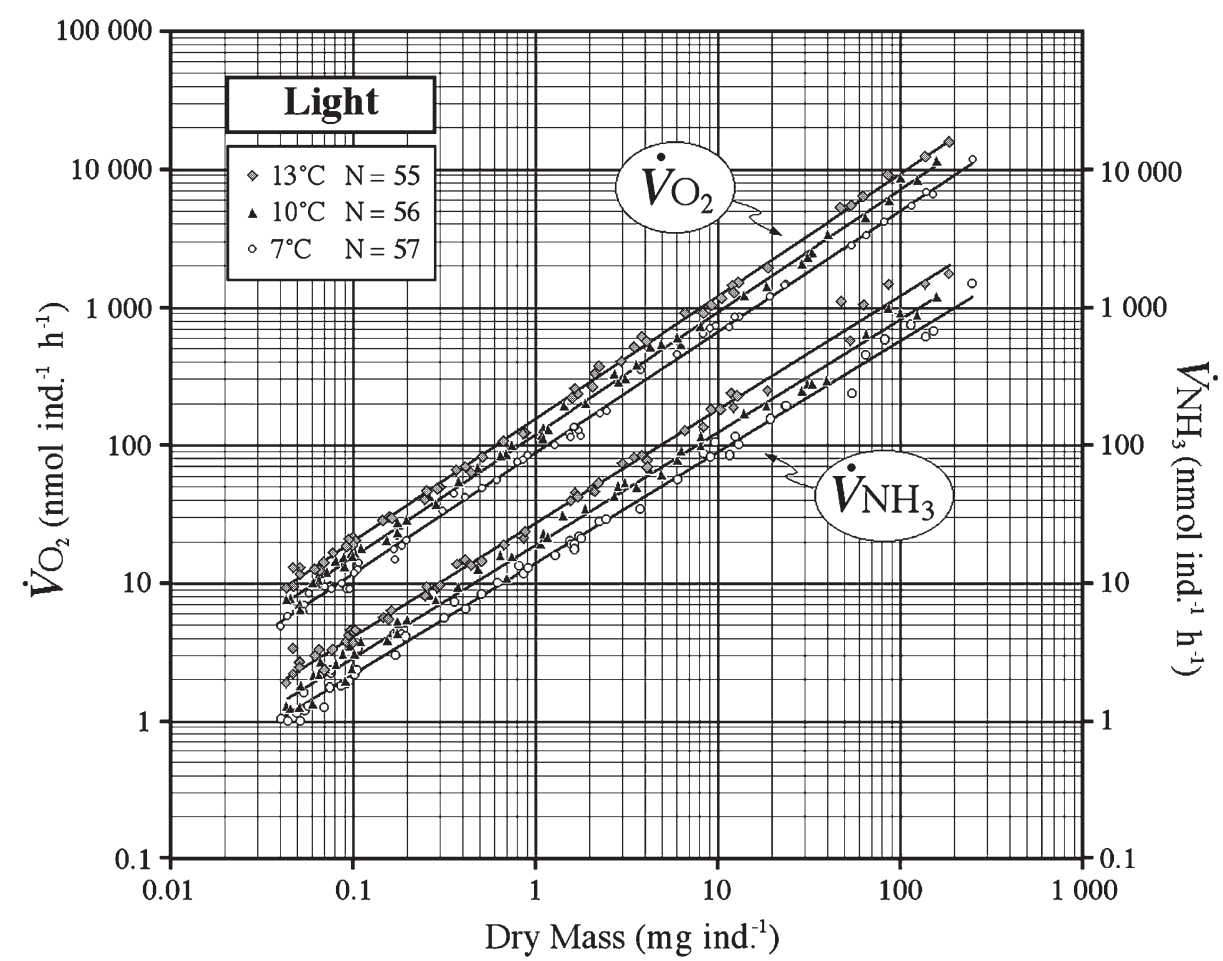


Table 2. Gadus morhua. Metabolic scaling constants and statistics for power equations of the form $y=a x^{b}$, Model-I least-squares regression and $y=u x^{v}$, Model-II geometric-mean regression. Data are analysed as described for Table 1. Eqs. (1)-(24) refer to Series-1 fasted larvae. Eqs. (25)-(32) refer to Series-2 experiments of fed and fasted larvae: F/light, fed larvae exposed to light; F/dark, fed larvae in darkness; S/light, fasted larvae exposed to light; and S/dark, fasted larvae in darkness. Eqs. (33) \& (34) refer to Series-3 fasted first-feeding stage larvae exposed to light. The amount of photon energy at the respirometer surface for light-adapted larvae was $10-25 \mu \mathrm{E} \mathrm{s}^{-1} \mathrm{~m}^{-2}$

\begin{tabular}{|c|c|c|c|c|c|c|c|c|c|}
\hline \multirow[t]{2}{*}{ Equation } & \multirow[t]{2}{*}{$T\left({ }^{\circ} \mathrm{C}\right)$} & \multirow{2}{*}{$\begin{array}{c}\text { Size } \\
\text { range }\end{array}$} & \multirow[t]{2}{*}{$\mathrm{N}$} & \multicolumn{2}{|c|}{ — Model I — } & \multicolumn{2}{|c|}{ — Model II — } & \multirow{2}{*}{$\begin{array}{c}95 \% \\
\text { CI }\end{array}$} & \multirow[t]{2}{*}{$\mathrm{r}^{2}$} \\
\hline & & & & $a$ & $b$ & $u$ & $v$ & & \\
\hline \multicolumn{10}{|c|}{ SERIES 1 EXPERIMENTS } \\
\hline \multicolumn{10}{|c|}{$\dot{V}_{\mathrm{O}_{2}}\left(\right.$ nmol ind. $\left.^{-1} \mathrm{~h}^{-1}\right)$ vs dry mass (mg ind..$^{-1}$ ) } \\
\hline (1) Light & 7 & $0.04-250$ & 57 & 88.59 & 0.878 & 88.58 & 0.879 & 0.010 & 0.998 \\
\hline$(2)$ & 10 & $0.04-200$ & 56 & 116.97 & 0.885 & 116.96 & 0.886 & 0.010 & 0.998 \\
\hline (3) & 13 & $0.04-200$ & 55 & 155.94 & 0.889 & 155.93 & 0.890 & 0.010 & 0.998 \\
\hline Dark & 7 & $0.04-225$ & 55 & 73.50 & 0.917 & 73.50 & 0.918 & 0.014 & 0.997 \\
\hline (5) & 10 & $0.04-150$ & 43 & 96.34 & 0.904 & 96.33 & 0.906 & 0.020 & 0.995 \\
\hline (6) & 13 & $0.04-150$ & 52 & 124.40 & 0.917 & 124.37 & 0.918 & 0.014 & 0.997 \\
\hline \multicolumn{10}{|c|}{$\dot{V}_{\mathrm{NH}_{3}}\left(\mathrm{nmol} \mathrm{ind.}^{-1} \mathrm{~h}^{-1}\right)$ vs dry mass (mg ind. $\left.{ }^{-1}\right)$} \\
\hline (7) Light & 7 & $0.04-250$ & 57 & 14.17 & 0.805 & 14.17 & 0.855 & 0.037 & 0.975 \\
\hline (8) & 10 & $0.04-200$ & 55 & 19.26 & 0.817 & 19.26 & 0.873 & 0.035 & 0.983 \\
\hline (9) & 13 & $0.04-200$ & 54 & 27.64 & 0.823 & 27.63 & 0.859 & 0.024 & 0.990 \\
\hline (10) Dark & 7 & $0.08-100$ & 41 & 12.31 & 0.818 & 12.28 & 0.824 & 0.031 & 0.986 \\
\hline (11) & 10 & $0.08-100$ & 40 & 16.57 & 0.844 & 16.55 & 0.852 & 0.040 & 0.981 \\
\hline$(12)$ & 13 & $0.08-100$ & 43 & 21.88 & 0.853 & 21.85 & 0.857 & 0.029 & 0.990 \\
\hline \multicolumn{10}{|c|}{$\dot{V}_{\mathrm{O}_{2}}\left(\mathrm{nmol}_{\text {ind. }} .^{-1} \mathrm{~h}^{-1}\right)$ vs wet mass (mg ind..$\left.^{-1}\right)$} \\
\hline (13) Light & 7 & $0.3-1300$ & 61 & 16.75 & 0.908 & 16.71 & 0.909 & 0.012 & 0.998 \\
\hline (14) & 10 & $0.3-820$ & 61 & 21.92 & 0.909 & 21.86 & 0.910 & 0.012 & 0.997 \\
\hline (15) & 13 & $0.3-920$ & 61 & 28.67 & 0.915 & 28.60 & 0.916 & 0.013 & 0.997 \\
\hline (16) Dark & 7 & $0.3-1140$ & 57 & 13.18 & 0.938 & 13.12 & 0.940 & 0.017 & 0.996 \\
\hline$(17)$ & 10 & $0.3-660$ & 55 & 18.49 & 0.918 & 18.39 & 0.921 & 0.021 & 0.993 \\
\hline$(18)$ & 13 & $0.3-800$ & 57 & 22.16 & 0.939 & 22.05 & 0.942 & 0.019 & 0.995 \\
\hline \multicolumn{10}{|c|}{$\dot{V}_{\mathrm{NH}_{3}}\left(\mathrm{nmol} \mathrm{ind.}^{-1} \mathrm{~h}^{-1}\right)$ vs wet mass (mg ind. $\left.{ }^{-1}\right)$} \\
\hline (19) Light & 7 & $0.3-1300$ & 61 & 3.07 & 0.834 & 3.05 & 0.837 & 0.018 & 0.997 \\
\hline$(20)$ & 10 & $0.3-820$ & 61 & 4.07 & 0.841 & 4.05 & 0.843 & 0.017 & 0.997 \\
\hline$(21)$ & 13 & $0.3-920$ & 61 & 5.77 & 0.840 & 5.72 & 0.844 & 0.022 & 0.995 \\
\hline (22) Dark & 7 & $0.7-530$ & 41 & 2.67 & 0.833 & 2.63 & 0.839 & 0.032 & 0.993 \\
\hline$(23)$ & 10 & $0.7-530$ & 40 & 3.50 & 0.858 & 3.42 & 0.867 & 0.043 & 0.989 \\
\hline$(24)$ & 13 & $0.7-530$ & 38 & 4.42 & 0.870 & 4.36 & 0.875 & 0.033 & 0.994 \\
\hline \multicolumn{10}{|c|}{ SERIES 2 EXPERIMENTS } \\
\hline \multicolumn{10}{|c|}{$\dot{V}_{\mathrm{O}_{2}}\left(\mathrm{nmol}\right.$ ind. $\left.{ }^{-1} \mathrm{~h}^{-1}\right)$ vs dry mass (mg ind..$\left.^{-1}\right)$} \\
\hline (25) F/light & 10 & $1.0-350$ & 42 & 149.36 & 0.818 & 148.93 & 0.820 & 0.015 & 0.997 \\
\hline (26) F/dark & 10 & $1.0-220$ & 35 & 108.48 & 0.867 & 108.12 & 0.868 & 0.017 & 0.997 \\
\hline (27) S/light & 10 & $1.0-300$ & 41 & 152.93 & 0.795 & 151.82 & 0.798 & 0.023 & 0.992 \\
\hline (28) S/dark & 10 & $1.0-500$ & 43 & 119.45 & 0.815 & 118.87 & 0.817 & 0.018 & 0.995 \\
\hline \multicolumn{10}{|c|}{$\dot{V}_{\mathrm{NH}_{3}}\left(\mathrm{nmol}_{\mathrm{ind}}{ }^{-1} \mathrm{~h}^{-1}\right)$ vs dry mass (mg ind. $\left.{ }^{-1}\right)$} \\
\hline (29) S/light & 10 & $1.0-350$ & 41 & 17.10 & 0.893 & 16.93 & 0.898 & 0.030 & 0.990 \\
\hline$(30)$ & 10 & $1.0-220$ & 35 & 10.98 & 0.992 & 10.84 & 0.997 & 0.037 & 0.989 \\
\hline (31) S/dark & 10 & $1.0-300$ & 41 & 26.40 & 0.573 & 25.97 & 0.580 & 0.030 & 0.975 \\
\hline$(32)$ & 10 & $1.0-500$ & 42 & 18.51 & 0.632 & 18.03 & 0.643 & 0.037 & 0.967 \\
\hline \multicolumn{10}{|c|}{ SERIES 3 EXPERIMENTS } \\
\hline \multicolumn{10}{|c|}{$\dot{V} \mathrm{O}_{2}\left(\right.$ nmol ind. $\left.^{-1} \mathrm{~h}^{-1}\right)$ vs dry mass (mg ind..$\left.^{-1}\right)$} \\
\hline (33) Light & 5 & $0.04-0.07$ & 69 & 90.65 & 0.990 & 88.58 & 1.648 & 0.332 & 0.339 \\
\hline \multicolumn{10}{|c|}{$\dot{V} \mathrm{NH}_{3}\left(\mathrm{nmol}\right.$ ind. $\left.^{-1} \mathrm{~h}^{-1}\right)$ vs dry mass $\left(\mathrm{mg} \mathrm{ind}^{-1}\right)$} \\
\hline (34) Light & 5 & $0.04-0.07$ & 64 & 42.35 & 1.380 & 478.15 & 2.210 & 0.438 & 0.390 \\
\hline
\end{tabular}


Fig. 5. Gadus morhua. Routine rate $\left(\mathrm{nmol}\right.$ ind.$\left.^{-1} \mathrm{~h}^{-1}\right)$ of oxygen uptake $\left(\dot{V}_{\mathrm{O}_{2}}\right)$ and ammonia excretion $\left(\dot{V}_{\mathrm{NH}_{3}}\right)$ related to dry mass of individual fasted larvae of Atlantic cod (Series 1) at 3 temperatures under conditions of darkness. Curves are modelled as described for Fig. 4

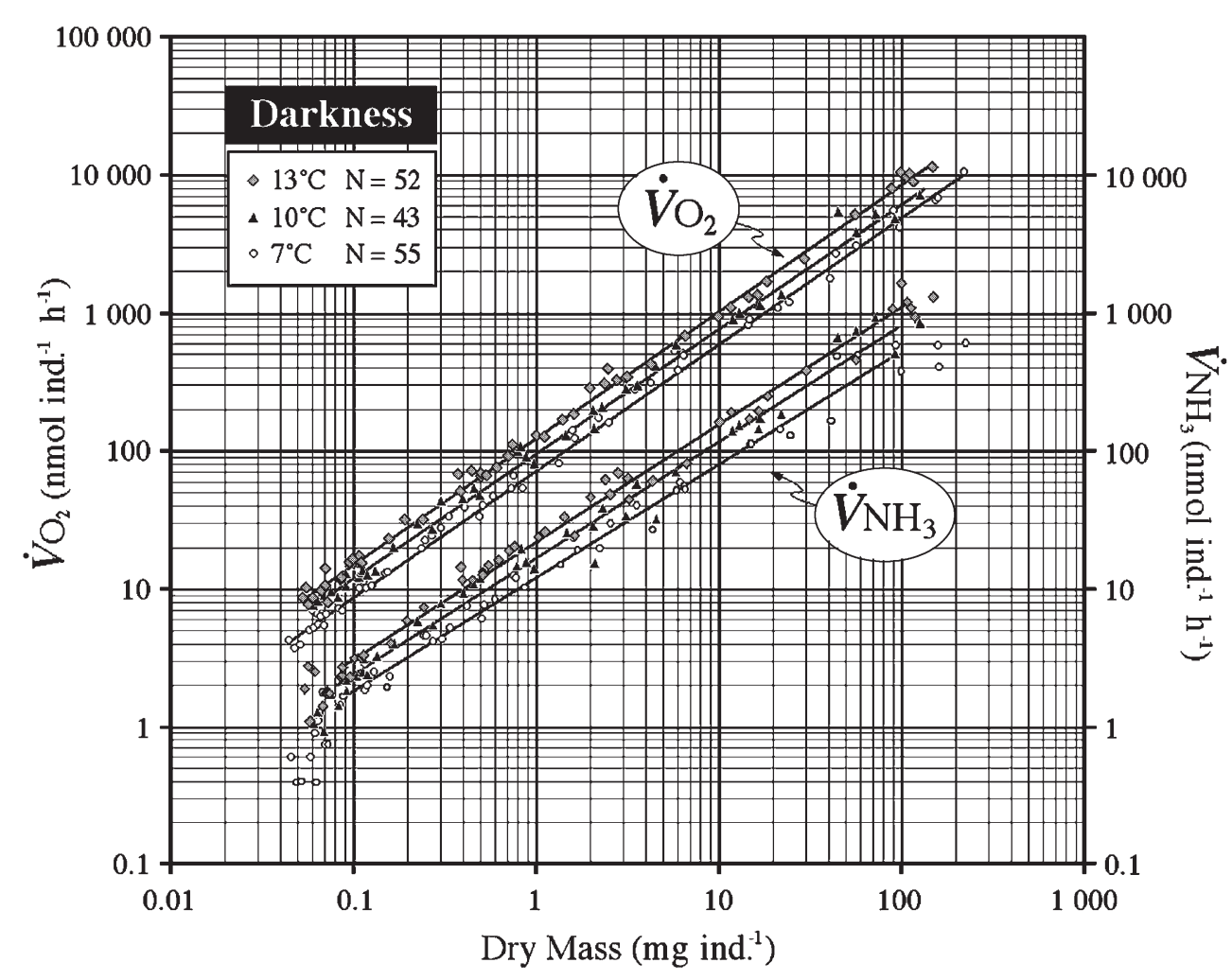

scaling $(b=1.380 \pm 0.438)$, while Model II $(v=2.210 \pm$ 0.438) was significantly higher than unity (Eq. 34; Table 2). The effect of light was similar to that described for $\dot{V}_{\mathrm{O}_{2}}$, where smaller larvae were stimulated to excrete greater amounts of $\mathrm{NH}_{3}$, and this effect declined with increasing size (data not shown). Modelling $\dot{V}_{\mathrm{NH}_{3}}$ against wet mass and dry mass revealed that temperature affected $\dot{V}_{\mathrm{NH}_{3}}$ with an average $Q_{10}$ of 2.88 to 3.06 for light-adapted larvae and 2.32 to 2.61 for dark-adapted larvae.

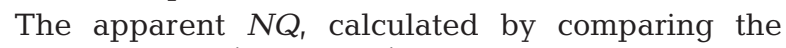
molar ratios of $\dot{V}_{\mathrm{NH}_{3}}$ and $\dot{V}_{\mathrm{O}_{2}}$ of the light- and darkadapted larvae, revealed that small larvae utilise greater amounts of amino acids as fuel than do larger larvae (Figs. $8 \& 9$ ). The data show that during the first phase of isometric growth (up to $7 \mathrm{~mm} \mathrm{SL}$ ) Atlantic cod larvae had high levels of amino-acid catabolism. If lipid was the dominant co-substrate, then amino-acid catabolism would have exceeded $70 \%$ of the total metabolic expenditure, and in some individuals amino acids may have constituted as much as 90 to $95 \%$ of fuel preference. No significant shift in fuel preference could be detected with increasing temperature in either light- or dark-adapted larvae; however, the dark-adapted larvae showed greater fluctuation in their $N Q$ s compared with light-adapted larvae. With continued growth and development, the $N Q$ of both

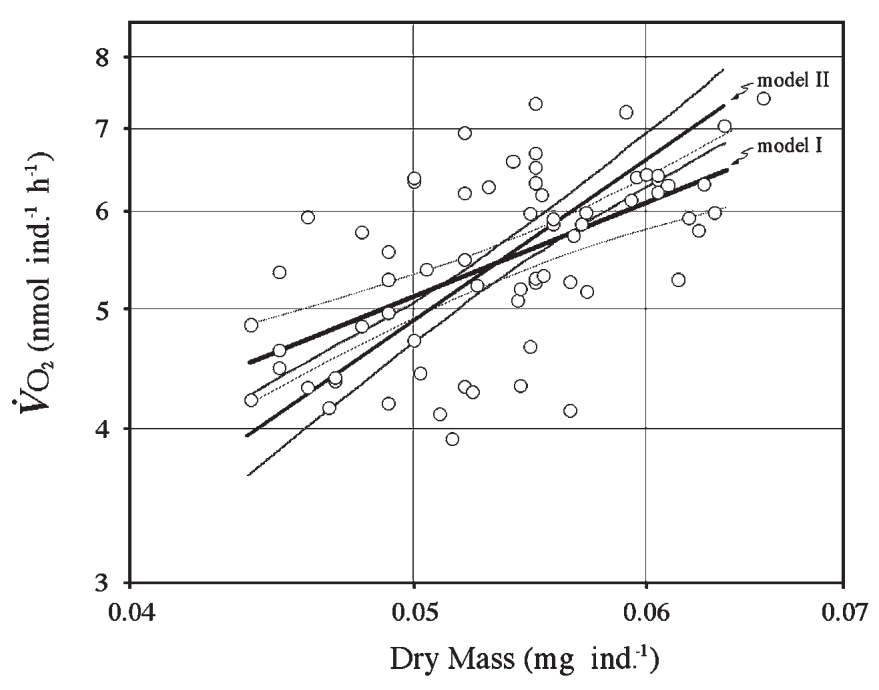

Fig. 6. Gadus morhua. Routine rate of oxygen uptake $\left(\dot{V}_{\mathrm{O}_{2}}\right.$ $\mathrm{nmol}$ ind.$^{-1} \mathrm{~h}^{-1}$ ) related to dry mass of individual first-feedingstage larvae of Atlantic cod (Series 3). The measurements were conducted at $5^{\circ} \mathrm{C}$ with larvae exposed to $10-25 \mu \mathrm{E} \mathrm{s}{ }^{-1}$ $\mathrm{m}^{-2}$ at the respirometer surface. Each data point represents the mean $\dot{V}_{\mathrm{O}_{2}}$ of $4-5$ pooled larvae $(\mathrm{N}=67$ separate measurements). The larvae were derived from the simultaneous spawnings of 14 female Atlantic cod and were reared at $5^{\circ} \mathrm{C}$ to the completion of yolk resorption. The respiration measurements were conducted (Day 26 post-fertilisation, first-feeding stage) when the last remnants of yolk had disappeared 


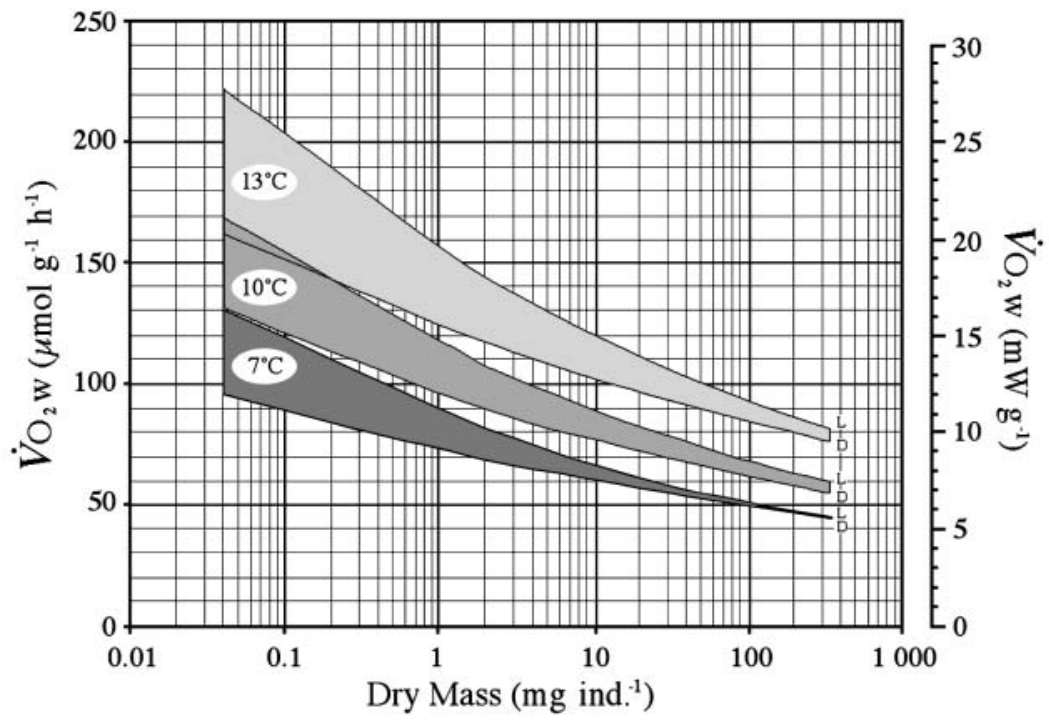

Fig. 7. Gadus morhua. Mass-specific routine rate of oxygen uptake $\left(\dot{V}_{\mathrm{O}_{2} \mathrm{w}}\right.$ $\mu \mathrm{mol} \mathrm{g}^{-1} \mathrm{~h}^{-1}$ ) related to dry mass of individual larvae and early juvenile Atlantic cod exposed to light $\left(10-25 \mu \mathrm{E} \mathrm{s}^{-1} \mathrm{~m}^{-2}\right)$ and darkness at 3 temperatures. The upper curves of each temperature region represents $\dot{V}_{\mathrm{O}_{2} \mathrm{w}}$ of lightadapted larvae (L), and the lower curves of each temperature region represents $\dot{V}_{\mathrm{O}_{2} \mathrm{w}}$ of dark-adapted larvae (D). The axis for the power rate of heat dissipation $\left(\mathrm{mW} \mathrm{g}^{-1}\right)$ is constructed using an oxycaloric equivalent of $450 \mathrm{~kJ}$ $\mathrm{mol}^{-1} \mathrm{O}_{2}$ (Gnaiger \& Kemp 1990). The circled numbers above the graph represent the 5 larvae depicted in Fig. 2

light- and dark-adapted individuals declined at each experimental temperature, and non-nitrogenous fuels became more important. However, even in juveniles (>12 mm SL) amino acids still constituted a substantial proportion of the total fuel budget, and, if lipids were the dominant co-substrate, would have supplied as much as 50 to $70 \%$ of the fuel preference.

Comparison of the $\dot{V}_{\mathrm{O}_{2}}$ of fed and shortterm-fasted cod juveniles (Series 2) at $10^{\circ} \mathrm{C}$ did not reveal a significant increase in the aerobic metabolic rate associated with feeding of the light-adapted juveniles of any size (Fig. 10; Eqs. 25 \& 27; Table 2). The same was true for darkadapted juveniles up to a dry mass of $10 \mathrm{mg}$ ind. ${ }^{-1}$, although the regression analyses over the full range of sizes examined revealed a small, but significantly ( $p<0.05$ ) lower, slope of the fasted juveniles (Fig. 11; Eqs. 26 \& 28; Table 2). Conversely, the drop in $\dot{V}_{\mathrm{NH}_{3}}$ of shortterm-fasted juveniles with dry masses above $60 \mathrm{mg}$ ind. $^{-1}$ (>35 mm SL) was highly significant, as reflected in the low regression coefficients of the short-termfasted juveniles compared to the fed juveniles (Eqs. 29-32; Table 2). For juve- niles less than $10 \mathrm{mg}$ ind. ${ }^{-1}$ dry mass ( $<20 \mathrm{~mm} \mathrm{SL}$ ), no significant depression of $\dot{V}_{\mathrm{NH}_{3}}$ was observed. The consequence of

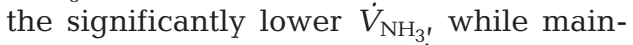
taining near-fed rates of $\dot{V}_{\mathrm{O}_{2}}$ is clearly seen when examining the $N Q$ s (Fig. 12). Short-term fasting did not influence the fuel preference of juveniles with SLs of less than $20 \mathrm{~mm}$, but may have caused a significant switch to non-nitrogenous fuels in juveniles with SLs in excess of $30 \mathrm{~mm}$. The presence or absence of light had no effect in this respect. Compared with the $N Q \mathrm{~s}$ of the short-term-fasted juveniles of Series 1, the NQs of Series-2 juveniles were lower.

\section{DISCUSSION}

There is considerable debate in the literature as to which regression model is most appropriate for the unbiased analysis of bivariate biological data (Ricker 1973, Laws \& Archie 1981, Giguère et al. 1988, Packard \& Boardman 1988, LaBarbera 1989, Post \& Lee 1996, Clarke \& Johnston 1999, Sokal \& Rohlf 2000). Statisticians argue unanimously that Model II (geometric-mean) regression yields the unbiased estimate of $y$ as a function of $x$, and

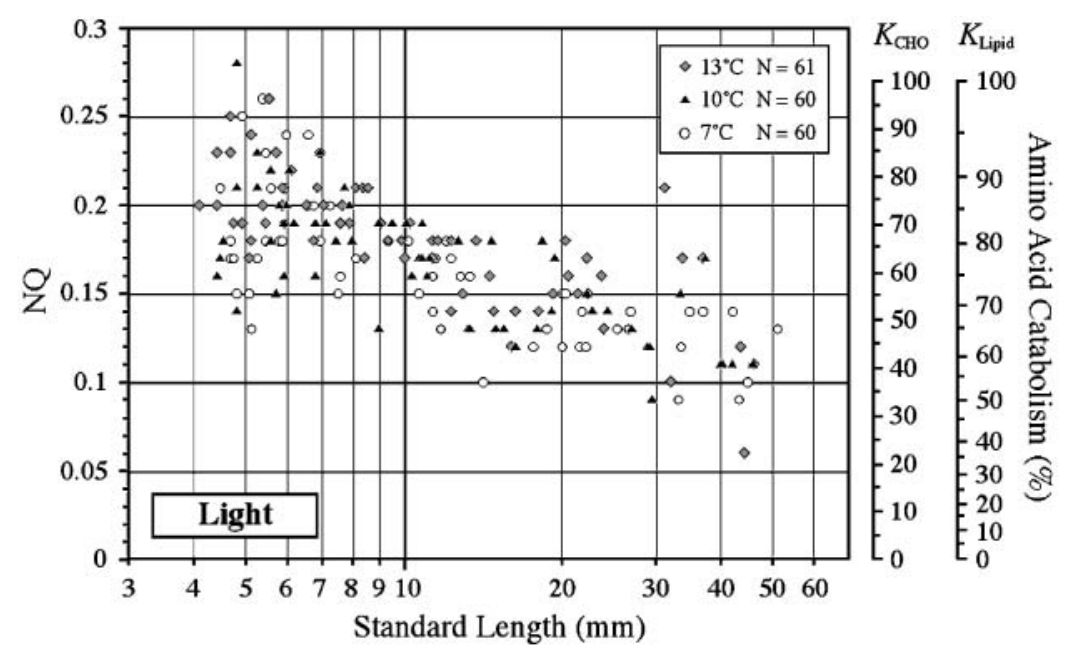

Fig. 8. Gadus morhua. Apparent nitrogen quotient (NQ) related to SL of larvae and early juvenile Atlantic cod at 3 temperatures exposed to light (10-25 $\mu \mathrm{E} \mathrm{s} \mathrm{s}^{-1} \mathrm{~m}^{-2}$ at the respirometer surface). Depending on which cosubstrate (carbohydrate $\left[K_{\mathrm{CHO}}\right]$ or lipid $\left[K_{\text {lipid }}\right]$ ) is catabolised, the $N Q$ yields an estimate of the relative contribution of amino acids as fuel. The 2 axes ([ $\left.K_{\mathrm{CHO}}\right]$ and $\left.\left[K_{\text {lipid }}\right]\right)$, denoting the relative fraction of amino-acid catabolism, were calculated following the recommendations of Gnaiger (1983). Note that, when lipid is the co-substrate catabilised, the relationship between the $N Q$ and the mass fraction of amino acids burned is non-linear 


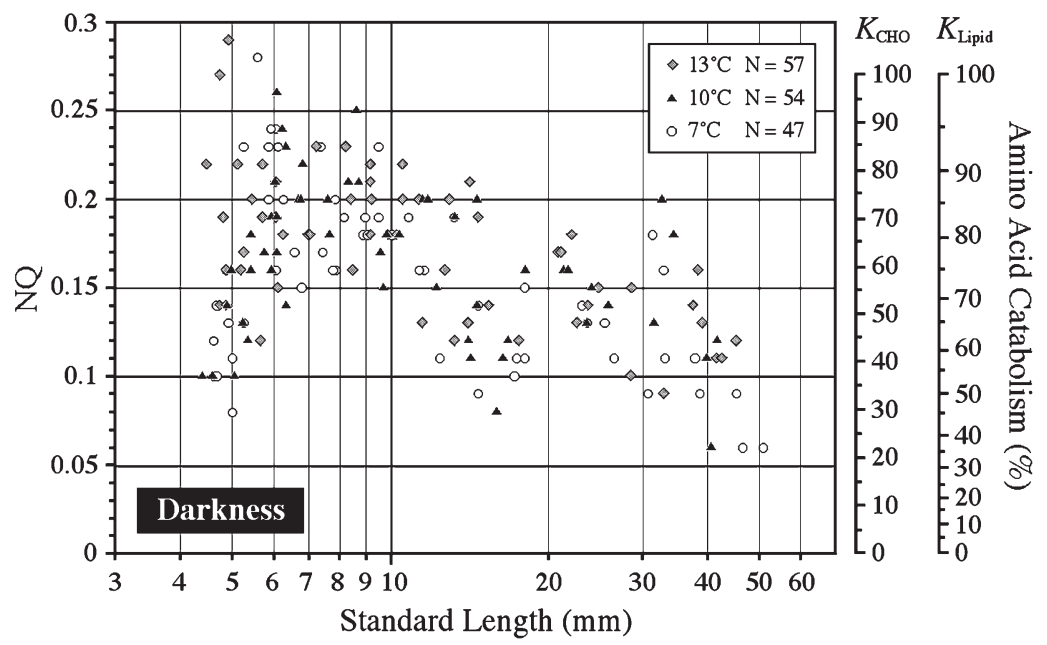

Fig. 9. Gadus morhua. Apparent nitrogen quotient (NQ) related to SL of larvae and early juvenile Atlantic cod at 3 temperatures under conditions of darkness. The fuel axes were constructed as described for Fig. 8 cal literature does not accept this thesis. Model-I regression, however, has the major disadvantage of being highly sensitive to outliers, since their influence is proportional to the square of their distance from the mean. As a result any slope derived from Model-I regression analysis is notoriously influenced by data points at either end of the scale. The debate of the most appropriate regression model is very much an ongoing one (Clarke \& Johnston 1999), and there is no simple answer. In part, to avoid the controversy, but also to ensure that our interpretations are not shackled by structural modelling, we chose to present both models.

Although the presented data are very low in variance and yield almost identical equations, regardless of the regression model applied, whenever the scale of the abcissa was reduced, the variance of the $x$ as a function of $y$. Since both data variates (i.e. respiration rate and body mass) were not controlled by the investigator, but vary independently, then Model-II techniques should be applied (Ricker 1973, Laws \& Archie 1981, Giguère et al. 1988, LaBarbera 1989, Sokal \& Rohlf 2000). In the literature, however, the great majority of studies have used the least-squares linear approach (Model I) to describe scaling relationships, usually arguing that the measurement of body mass can be achieved with a minimum of error due to the precision of modern microbalances. This seems a reasonable approach, despite the fact that the statisti-

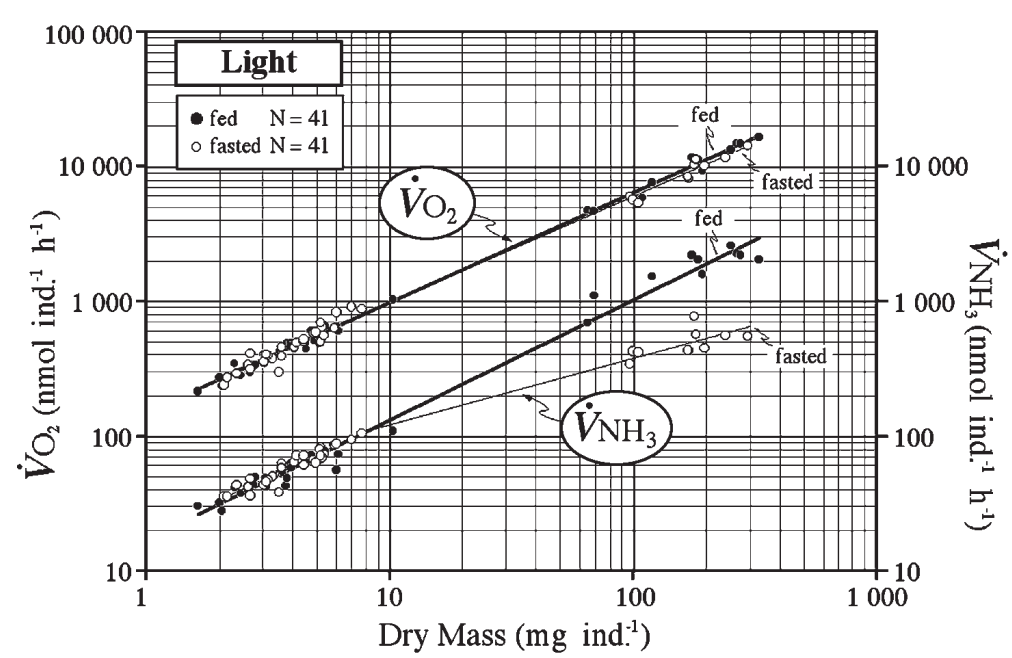

Fig. 10. Gadus morhua. Rate (nmol ind..$\left.^{-1} \mathrm{~h}^{-1}\right)$ of oxygen uptake $\left(\dot{V}_{\mathrm{O}_{2}}\right)$ and ammonia excretion $\left(\dot{V}_{\mathrm{NH}_{3}}\right)$ related to dry mass of individual fed and fasted larvae and early juvenile Atlantic cod (Series 2) at $10^{\circ} \mathrm{C}$ exposed to $10-25 \mu \mathrm{E} \mathrm{s}^{-1} \mathrm{~m}^{-2}$ at the respirometer surface. Curves are modelled as described for Fig. 4 data was too great to arrive at some reasonable estimate of the exponent (Eqs. 33 \& 34; Table 2). The finding that the metabolic exponent of the Series-3 experiments (14 groups of first-feeding larvae) did not differ significantly from unity does not necessarily mean that the metabolic rate of Atlantic cod larvae scales isometrically with body mass. We consider the abscissal scale to be insufficient to arrive at such a conclusion. The overwhelming empirical evidence of the $\dot{V}_{\mathrm{O}_{2}}$ of Series-1 and Series-2 experiments, regardless of temperature or exposure to light, argues strongly that the routine metabolic rate of Atlantic cod larvae and early juveniles does not scale isometrically with body mass. Indeed, an allometric scaling of metabolic rate with body size in Atlantic cod is unambiguously supported in the literature, regardless of stage investigated (Sundnes 1957, Saunders 1963, Edwards et al. 1972, Laurence 1978, Serigstad 1987a).

The current findings are thus at odds with the hypothesis of Giguère et al. (1988), who believed that metabolic rates scale isometrically in larval fishes, and also with the proposal of Bochdansky \& Legget (2001), who argue that metabolic scaling during ontogeny is curvilinear. The present routine metabolic data also do not fit the first isometric or near-isometric phase deduced by Post \& Lee (1996). These earlier studies did not provide any fundamental reason other than careful experimentation and statistical analyses for their general assessments. There is little doubt 


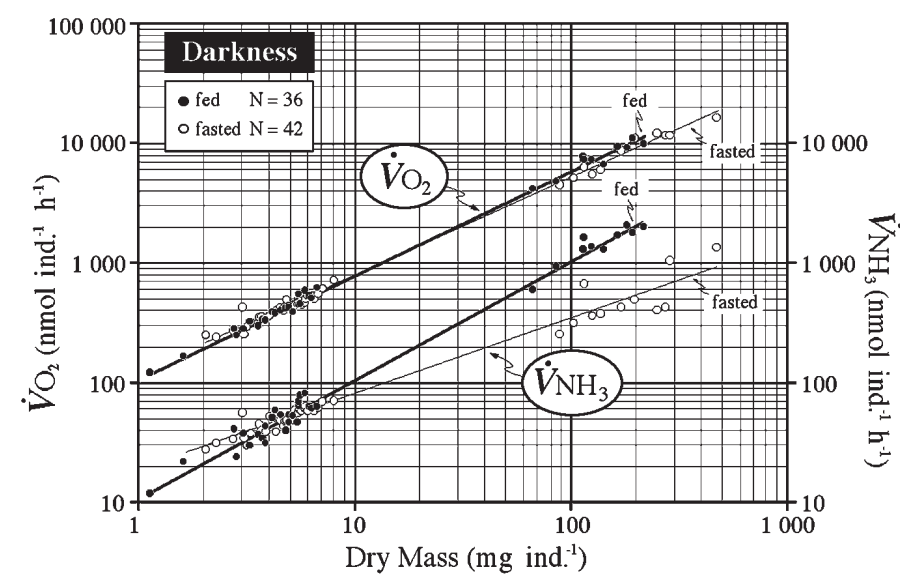

Fig. 11. Gadus morhua. Rate (nmol ind. ${ }^{-1} \mathrm{~h}^{-1}$ ) of oxygen uptake $\left(\dot{V}_{\mathrm{O}_{2}}\right)$ and ammonia excretion $\left(\dot{V}_{\mathrm{NH}_{3}}\right)$ related to dry mass of individual fed and fasted larvae and early juvenile Atlantic cod (Series 2) at $10^{\circ} \mathrm{C}$ under conditions of darkness. Curves are modelled as described for Fig. 4

that some larval fishes scale isometrically with body size (e.g. Atlantic mackerel Scomber scombrus, Giguère et al. 1988; Chinook salmon Oncorhynchus tshawitscha, Rombough 1994; and Atlantic halibut Hippoglossus hippoglossus, Rønnestad \& Naas 1993, Finn et al. 1995d), but it is clear that the generalisation for all fish larvae is not valid. This agrees with the views of Wieser (1995). We are therefore faced with trying to explain the fact that Atlantic cod larvae, even at the very earliest stages of their life cycle, do not have metabolic rates that are proportional to their body size. The allometric metabolic exponent is maintained throughout the life of Atlantic cod and does not equate to the general larval isometry (Giguère et al. 1988), nor to the 3/4-power scaling coefficient first noted by Kleiber (1932). In recent years, several articles have argued that it is the fractal vascular networks of plants and animals which limit the supply of nutrients to cells in such a way as to dictate a quarter-power scaling law (West et al. 1997, 1999, 2001, 2002, Banavar et al. 1999, Enquist et al. 1999). Indeed, Bochdansky \& Leggett (2001) used the vascular argument modulated by the surface law as the basis of one of their structural terms and the isometric argument of Giguère et al. (1988) for the other term. Others have argued that the relative importance of branchial or cutaneous gas exchange may be the cause of the observed scaling coefficient (Hughes 1984, Hughes \& Al-Kadhomiy 1988). More recently, Oikawa \& Itazawa
(1993) and Wells \& Pinder (1996a,b) have concluded that there is little evidence that respiration in larval fishes becomes limited by respiratory surface area, and Rombough \& Moroz (1997) and Rombough (1998) have argued that, despite dealing with gas exchange, the primary function of gills in fish larvae is more related to ionoregulation. We agree with these latter ideas, and thus argue that some other reason must be found for the observed metabolic exponents of 0.88 and 0.91 in the early life stages of Atlantic cod (Series 1) in light and darkness, respectively.

The 2 bivariate parameters that are measured are routine $\dot{V}_{\mathrm{O}_{2}}$ and body mass. Routine $\dot{V}_{\mathrm{O}_{2}}$ as discussed by Fry (1957) and Beamish \& Dickie (1967) includes all metabolic levels between standard and active rates, and it applies to measurements conducted on spontaneously active larvae. The point here is that the routine metabolic rate is one that is not forced, i.e. oxygen delivery is not limited, and cellular metabolism is not stressed to its maximum, but lies at the lower end of the metabolic scope. Since the actual site of oxygen consumption occurs at the end of the electron-transport system within the mitochondrial matrix, it seems logical that the metabolic rate might in some way be related to the amount of mitochondria in the organism. Using histological and stereological techniques, Galloway et al. (1998) found that the axial swimming musculature is the largest and most rapidly growing tissue in the larval body. Galloway et al. (1999) also report, albeit for a limited size range, that the white-muscle fractions grow at faster rates than the red muscle in Atlantic cod larvae. The white fibres in Atlantic cod larvae constituted approximately $80 \%$ of the muscle cross-sectional area at first feeding ( $4 \mathrm{~mm} \mathrm{SL}$ ) and $90 \%$ at $7.5 \mathrm{~mm}$ SL. This rep-

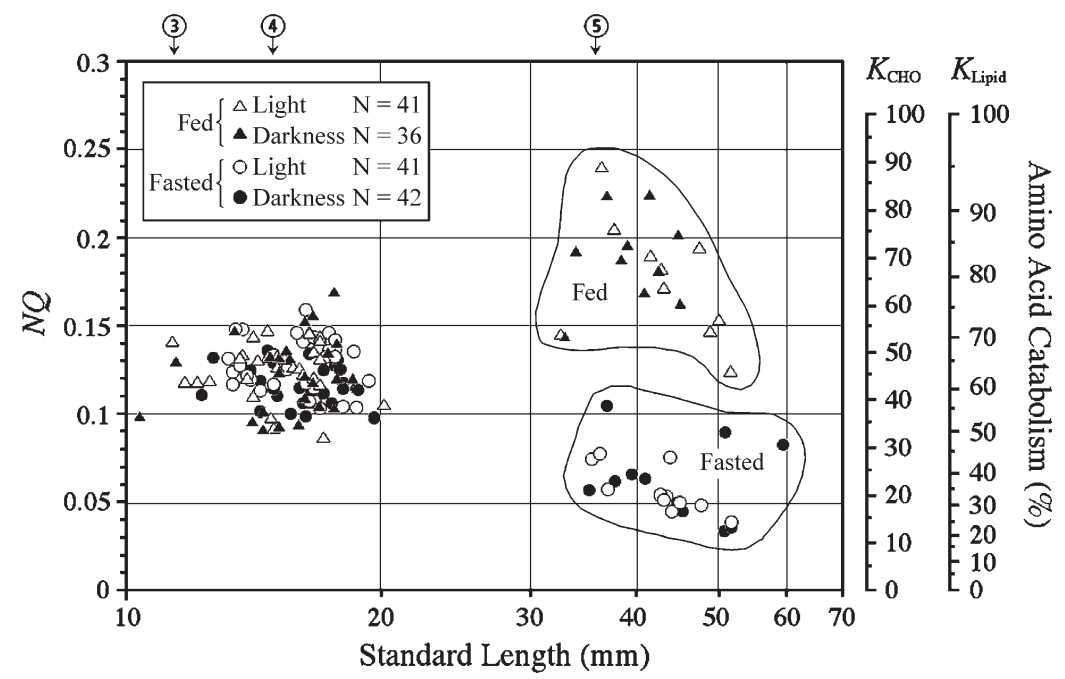

Fig. 12. Gadus morhua. Apparent nitrogen quotient (NQ) related to SL of larvae and early juvenile Atlantic cod at $10^{\circ} \mathrm{C}$ under conditions of darkness. The fuel axes were constructed as described for Fig. 8 
resents the isometric growth phase of the larvae, when body mass is increasing to the cube power of SL (Table 1). The density of mitochondria in the red- and white-muscle fibres of Atlantic cod larvae was also found to change with development, such that the fraction of red-muscle mitochondria increases while that of the white muscle decreases (T. F. Galloway pers. comm.). The suggestion is therefore that there is an ontogenetic reorganisation of tissues which form part of the body mass but which contribute less to the $\dot{V}_{\mathrm{O}^{\prime}}$ and, as a result, aerobic metabolic rate scales allometrically with size even in the earliest stages of Atlantic cod larvae. The reorganisation for Atlantic cod is suggested to be primarily the allometric development of white muscle, but could easily be other forms of ametabolic tissues (e.g. the labile energy stores of leptocephalus larvae) and as such will be species or even race specific, as indicated by the many separate regression lines plotted by Post \& Lee (1996). Such a tissue-specific basis for the mass-metabolic exponent has already been discussed (Itazawa \& Oikawa 1983, Oikawa \& Itazawa 1983, 1985, 1993, Wieser 1995) and most recently argued by Darveau et al. (2002). An exaggerated example of allometric metabolic scaling is seen in the leptocephalus larvae studied by Pfeiler \& Govoni (1993) and Bishop \& Torres (1999). Leptocephalus larvae have the remarkable adaptation of accumulating ametabolic energy stores in the form of proteoglycans and glycosaminoglycan carbohydrates (Pfeiler 1996, Bishop et al. 2000) which contribute to the body mass but not to the metabolic rate.

The present data for Atlantic cod larvae clearly demonstrate that, given unlimited food supplies, temperature, light and body size are the principle extrinsic and intrinsic factors governing the metabolic rate. Previous studies have demonstrated that temperature and size are the greatest determinants of growth in Norwegian coastal and northeast Arctic Atlantic cod larvae (Otterlei et al. 1999, Otterlei 2000). These earlier studies also noted that instantaneous growth rates can exceed $25 \% \mathrm{~d}^{-1}$, as found in the present study. Otterlei et al. (1999) found that maximum growth rates of Atlantic cod occur in larvae of less than $1 \mathrm{mg}$ ind. ${ }^{-1}$ dry mass. If we assumed, as a worst-case scenario, that $75 \%$ of the smallest larvae in the present study either died or were eaten, then instantaneous growth rates would still have exceeded $25 \% \mathrm{~d}^{-1}$. Thus, although we cannot rule out the possibility of cannibalism or sizeselective mortality in the mesocosms, the present data indicate that such high growth rates may be maintained beyond metamorphosis.

During the $48 \mathrm{~d}$ study period of Series 1, the increase in larval body mass spanned 5 orders of magnitude. According to Scott \& Scott (1988, cited by Fahay et al. 1999) the largest Atlantic cod ever recorded was
$95.9 \mathrm{~kg}$, which means that during the life of Atlantic cod body mass spans 9 orders of magnitude. To achieve the ninth order of magnitude, however, cod will need to grow for perhaps another 30 to $40 \mathrm{yr}$ (11000 to $14600 \mathrm{~d})$. The comparison emphasises that one of the main missions of fish larvae during their early life is to grow. A second point worth noting is that during these $48 \mathrm{~d}$ of growth, the Atlantic cod larvae increased their size in the same scale as a mouse to a horse. Had we continued our studies for another $2 \mathrm{wk}$, the cod larvae would have scaled from mouse to elephant, but the metabolic exponent of $\dot{V}_{\mathrm{O}_{2}}$ as a function of body mass was significantly higher than the 0.75 noted for the well-known mouse-to-elephant curve (Eckert 1997). As noted by others (Heusner 1982, Feldman \& McMahon 1983, Riisgård 1998) even a small difference in the scaling exponent has profound effects over several orders of magnitude. Indeed, if the metabolic exponent of $\dot{V}_{\mathrm{O}_{2}}$ versus dry body mass had been 0.76 (i.e. different only at the second decimal), then, even over the 5 orders of magnitude found, $\dot{V}_{\mathrm{O}_{2}}$ would have been $6 \%$ higher in the largest larvae (350 mg ind. ${ }^{-1}$ dry mass) compared with those modelled with an exponent of 0.75 . The observation that the metabolic exponent was actually 0.88 to 0.91 means that $\dot{V}_{\mathrm{O}_{2}}$ in the largest larvae was between 115 and $150 \%$ higher than for an equivalently sized larva that had scaled according to the $3 / 4$-power law.

The effect of acute acclimation to temperature of between 7 and $13^{\circ} \mathrm{C}$, with additional measurements at $5^{\circ} \mathrm{C}$, shows that metabolic scaling of the early life stages of Atlantic cod is not affected by altered environmental temperature. Rather, the metabolic rate shifts up or down in an exponential relation to the increase or decrease in temperature. These findings are supported by the studies of Giguère et al. (1988) for larval mackerel. Modelling the aerobic metabolic rate of light-adapted larvae of Atlantic cod at first-feeding (dry mass $=0.06 \mathrm{mg}$ ind. ${ }^{-1}$ ) measured at 5, 7, 10 and $13^{\circ} \mathrm{C}$ in the present study revealed an almost perfect exponential relationship between routine $\dot{V}_{\mathrm{O}_{2}}$ and temperature, $T\left(\dot{V}_{\mathrm{O}_{2}}=63.349 \mathrm{e}^{0.094 T} ; r^{2}=0.9999\right)$. The exponent 0.094 of the light-adapted larvae is unaffected by size, and hence, using the same procedure for the early life stages in darkness, we can derive 2 general equations describing the aerobic metabolic rate of Atlantic cod:

$$
\begin{aligned}
& \dot{V}_{\mathrm{O}_{2}}\left(\mathrm{nmol} \text { ind } .^{-1} \mathrm{~h}^{-1}\right) \text { in light }= \\
& 45.824 \text { dry mass }^{0.8851} \mathrm{e}^{(0.094 T)} \\
& \dot{V}_{\mathrm{O}_{2}}\left(\mathrm{nmol} \text { ind. }{ }^{-1} \mathrm{~h}^{-1}\right) \text { in darkness }= \\
& 39.879 \text { dry mass } \\
& 0.9124 \mathrm{e}^{(0.0877 T)}
\end{aligned}
$$

where dry mass is in mg ind. ${ }^{-1}$ and $T$ in ${ }^{\circ} \mathrm{C}$. For estimation of the power rate of heat dissipation in $\mu \mathrm{W}$ ind. ${ }^{-1}$, 
the product of the above equations can be multiplied by 0.125 . Similary for the $\dot{V}_{\mathrm{NH}_{3}}$ the 2 equations are

$$
\begin{aligned}
& \dot{V}_{\mathrm{NH}_{3}}\left(\text { nmol ind }^{-1} \mathrm{~h}^{-1}\right) \text { in light }= \\
& 6.761 \text { dry mass }^{0.8118} \mathrm{e}^{(0.1075 T)} \\
& \dot{V}_{\mathrm{NH}_{3}}\left(\text { nmol ind }^{-1} \mathrm{~h}^{-1}\right) \text { in darkness }= \\
& 6.351 \text { dry mass }^{0.8337} \mathrm{e}^{(0.095 T)}
\end{aligned}
$$

Such general equations are of the form given by Giguère et al. (1988) and most recently promoted by Gillooly et al. (2001, 2002), who argued that models based on $Q_{10}$ coefficients can result in errors of up to $15 \%$.

The classical $Q_{10}$ estimates of the effect of temperature on routine metabolic rate do, however, provide a conveniently recognisable scale for the thermal sensitivity of reaction rates, and they were therefore calculated for mean metabolic exponents of light- and darkadapted larvae. Since temperature did not significantly affect the metabolic exponents of either light- or darkadapted individuals, there was no statistical basis for suggesting a size-related effect of temperature on the metabolic rate of larval and early juvenile Atlantic cod. Hence we find that between 7 and $13^{\circ} \mathrm{C}$ dark-adapted larvae have a mean $Q_{10}$ of 2.4 , while light-adapted larvae have a mean $Q_{10}$ of 2.6 for the size ranges studied. These quotients will also apply to light-adapted larvae down to $5^{\circ} \mathrm{C}$. Our findings are therefore in good agreement with those reviewed by Rombough (1988) and Clarke \& Johnston (1999) for within species thermal sensitivity, and they support the earlier notion that teleost red-muscle mitochondria have only evolved modest adjustments for temperature adaptation (Johnston et al. 1994).

Marine fish larvae are quite capable of utilising glycolytic pathways for substrate phosphorylation, but these pathways are overshadowed by the activities of the tri-carboxylic acid cycle enzymes (Wieser 1991, Segner et al. 1994, Overnell \& Batty 2000). This is hardly surprising considering that the majority of fish larvae are carnivorous and adapted to deal with the amino-acid surge associated with the digestion of prey organisms. Since lipids are preferentially catabolised in juvenile and adult fishes (Wood 2001), we assume that lipids are also the co-substrate for interpreting the apparent $N Q$ data for Atlantic cod larvae. Indeed, both polar and neutral lipids were found to comprise the major co-substrate of Atlantic cod during yolk resorption (Finn et al. 1995a,b).

Although most nitrogen is excreted as ammonia in fish larvae (Wright \& Fyhn 2001), recent studies of marine fish larvae, including Atlantic cod, indicate that urea can be a significant form of waste nitrogen (Chadwick \& Wright 1999, Terjesen et al. 2002). These findings are in contrast to the situation for adult Atlantic cod, where activities of urea cycle enzymes are low (Chadwick \& Wright 1999). Nevertheless, if significant amounts of urea derived from deamination of ingested amino acids do occur, then the apparent $N Q \mathrm{~s}$ are minimum estimates of the mass fraction of amino acids utilised as fuel. Any ammonia production from adenylate deamination resulting from burst swimming events will not affect this interpretation, since most ammonia is retained intracellularly (Wood 2001).

Few studies have examined the effect of feeding on $\dot{V}_{\mathrm{O}_{2}}$ in fish larvae, although an increased thermogenesis associated with feeding is well known in juveniles and adults (Jobling 1981, 1994, Blaikie \& Kerr 1996). For marine fish larvae, Giguère et al. (1988) found an increased metabolic rate in fed mackerel larvae, as did Torres et al. (1996) in fed larvae of red drum Sciaenops ocellatus. The major difference between the findings of these studies was that Giguère et al. (1988) did not observe any effect of food on metabolic scaling, while Torres et al. (1996), based on considerably less data, suggested that the presence of food can elevate the metabolic exponent. The lack of difference in the $\dot{V}_{\mathrm{O}_{2}}$ of fed versus short-term-fasted Atlantic cod larvae in the present study may in part be due to the $1 \mathrm{~h}$ acclimation period prior to experimentation or to increased spontaneous activity associated with hunger in the short-term-fasted group.

Regarding the metabolic fuel of the larvae in the present study, no difference in the $N Q$ was seen between fed and short-term-fasted larvae of less than $20 \mathrm{~mm}$ SL ( 10 mg ind. ${ }^{-1}$ dry mass). In larvae greater than $30 \mathrm{~mm}$ SL ( 40 mg ind. ${ }^{-1}$ dry mass) a substantial decrease in the $\dot{V}_{\mathrm{NH}_{3}}$ compared to the $\dot{V}_{\mathrm{O}_{2}}$ was observed in the short-term-fasted larvae, suggesting a major switch in the fuel preference. Since adult fishes do not show altered daily rates of urea excretion even in the presence or absence of food (Wood 2001), we suggest that short-term-fasted juveniles of Atlantic cod are capable of conserving amino acids, rather than funneling them into the tri-carboxylic acid cycle.

In conclusion we find that the routine metabolic rate of Atlantic cod larvae scales allometrically with body mass. This functional relationship is not altered by increased temperature. Light causes a 1.4-fold elevation in routine metabolic rate of first-feeding larvae, but becomes less influential with increasing size, until no effect is seen in metamorphosed juveniles. Increasing acclimation temperature results in $Q_{10}$ effects of 2.4 and 2.6 in dark- and light-adapted larvae, respectively. Atlantic cod larvae show a high preference for amino acids as their major fuel during the first 3 to $4 \mathrm{wk}$ of post-hatch development. Juveniles seem capable of switching fuels during shortterm fasting events, and thereby conserve amino acids. 
Acknowledgements. We are grateful to Marianne Meling for assistance with the respiration studies of the cod larvae at $5^{\circ} \mathrm{C}$, and we are indebted to Trina Galloway for furnishing mitochondrial density data of Atlantic cod red and white axial muscle. Per Solemdal kindly provided the Series-3 cod eggs. The study was supported by the Norwegian Research Council (grants 121695/122, 141990/120), and is contribution no. 114 of the Marine Larvae Locus at the University of Bergen.

\section{LITERATURE CITED}

Banavar JR, Maritan A, Rinaldo A (1999) Size and form in efficient transportation networks. Nature 399:130

Beamish FWH, Dickie LM (1967) Metabolism and biological production in fish. In: Gerking SD (ed) The biological basis of freshwater fish production. Blackwell, Oxford, p 215-242

Bishop RE, Torres JJ (1999) Leptocephalus energetics: metabolism and excretion. J Exp Biol 202:2485-2493

Bishop RE, Torres JJ, Crabtree RE (2000) Chemical composition and growth indices in leptocephalus larvae. Mar Biol 137:205-214

Blaikie HB, Kerr SR (1996) Effect of activity level on apparent heat increment in Atlantic cod, Gadus morhua. Can J Fish Aquat Sci 53:2093-2099

Bochdansky AB, Leggett WC (2001) Winberg revisited: convergence of routine metabolism in larval and juvenile fish. Can J Fish Aquat Sci 58:220-230

Bower CE, Holm-Hansen T (1980) A salicylate-hypochlorite method for determining ammonia in seawater. Can J Fish Aquat Sci 37:794-798

Buckley LJ, Lough RG, Peck MA, Werner FE (2000) Comment: larval Atlantic cod and haddock growth models, metabolism, ingestion, and temperature effects. Can J Fish Aquat Sci 57:1957-1960

Bushnell PG, Steffensen JF, Schurmann, Jones DR (1994) Exercise metabolism of two species of cod in arctic waters. Polar Biol 14:43-48

Cerqueira VR, Brugger AM (2001) Effect of light intensity on initial survival of fat snook (Centropomus parallelus, Pisces: Centropomidae) larvae. Braz Arch Biol Techn 44:343-349

Chadwick TD, Wright PA (1999) Nitrogen excretion and expression of urea cycle enzymes in the Atlantic cod: a comparison of early life stages with adults. J Exp Biol 202: 2653-2662

Claireaux G, Webber DM, Kerr SR, Boutilier RG (1995a) Physiology and behaviour of free-swimming Atlantic cod (Gadus morhua) facing fluctuating temperature conditions. J Exp Biol 198:49-60

Claireaux G, Webber DM, Kerr SR, Boutilier RG (1995b) Physiology and behavior of free-swimming Atlantic cod (Gadus morhua) facing fluctuating salinity and oxygenation conditions J Exp Biol 198:61-69

Claireaux G, Webber DM, Lagardère JP, Kerr SR (2000) Influence of water temperature and oxygenation on the aerobic metabolic scope of Atlantic cod (Gadus morhua). J Sea Res 44:257-265

Clarke A, Johnston NM (1999) Scaling of metabolic rate with body mass and temperature in teleost fish. J Anim Ecol 68: 893-905

Darveau CA, Suarez RK, Andrews RD, Hochachka PW (2002) Allometric cascade as a unifying principle of body mass effects on metabolism. Nature 417:166-170

Davenport J, Lønning S (1980) Oxygen uptake in developing eggs and larvae of the cod (Gadus morhua). J Fish Biol 16: 249-256
Davenport J, Lønning S, Kjørsvik E (1983) Ammonia output by the eggs and larvae of the lumpsucker (Cyclopterus lumpus) the cod (Gadus morhua) and the plaice (Pleuronectes platessa). J Mar Biol Assoc UK 63:713-723

De Silva CD, Premawansa S, Keemiyahetty CN (1986) Oxygen consumption in Oreochromis niloticus (L.) in relation to development, salinity, temperature and time of day. J Fish Biol 29:267-277

Downing G, Litvak MK (2001) The effect of light intensity and spectrum on the incidence of first feeding by larval haddock. J Fish Biol 59:1566-1578

Dutil JD, Lambert Y, Boucher E (1997) Does higher growth rate in Atlantic cod (Gadus morhua) at low salinity result from lower standard metabolic rate or increased protein digestibility? Can J Fish Aquat Sci 54(Suppl 1):99-103

Eckert R (1997) Animal physiology. Mechanisms and adaptation. WH Freeman, New York

Edwards RRC, Finlayson DM, Steele JH (1972) An experimental study of the oxygen consumption, growth, and metabolism of the cod (Gadus morhua L.). J Exp Mar Biol Ecol 7:299-309

Enquist BJ, West GB, Charnov EL, Brown JH (1999) Allometric scaling of production and life-history variation in vascular plants. Nature 401:907-911

Fahay MP, Berrien PL, Johnson DL, Morse WW (1999) Atlantic cod, Gadus morhua, life history and habitat characteristics. NOAA Tech Memo NMFS-NE-124

Feldman HA, McMahon TA (1983) The 3/4 mass exponent for energy metabolism is not a statistical artifact. Resp Physiol 52:149-163

Finn RN (1994) Physiological energetics of developng marine fish embryos and larvae. PhD thesis, University of Bergen

Finn RN, Fyhn HJ, Evjen MS (1995a) Physiological energetics of developing embryos and yolk-sac larvae of Atlantic cod (Gadus morhua). I. Respiration and nitrogen metabolism. Mar Biol 124:355-369

Finn RN, Henderson RJ, Fyhn HJ (1995b) Physiological energetics of developing embryos and yolk-sac larvae of Atlantic cod (Gadus morhua). II. Lipid metabolism and enthalpy balance. Mar Biol 124:371-379

Finn RN, Widdows J, Fyhn HJ (1995c) Calorespirometry of developing embryos and yolk-sac larvae of turbot (Scophthalmus maximus). Mar Biol 122:157-163

Finn RN, Rønnestad I, Fyhn HJ (1995d) Respiration, nitrogen and energy metabolism of developing yolk-sac larvae of Atlantic halibut (Hippoglossus hippoglossus L.). Comp Biochem Physiol 111A: 647-671

Forstner H, Gnaiger E (1983) Calculation of equilibrium oxygen concentration. In: Gnaiger E, Forstner H (eds) Polarographic oxygen sensors. Aquatic and physiological applications. Springer-Verlag, New York, p 321-333

Fry FEJ (1957) The aquatic respiration of fish. In: Brown MF (ed) The physiology of fishes, Vol 1. Academic Press, New York, p 1-63

Fyhn HJ, Serigstad B (1987) Free amino acids as energy substrate in developing eggs and larvae of the cod (Gadus morhua). Mar Biol 96:335-341

Galloway TF, Kjørsvik E, Kryvi H (1998) Effect of temperature on viability and axial muscle development in embryos and yolk sac larvae of the Northeast Arctic cod (Gadus morhua). Mar Biol 132:559-567

Galloway TF, Kjørsvik E, Kryvi H (1999) Muscle growth and development in Atlantic cod larvae (Gadus morhua L.) related to different somatic growth rates. J Exp Biol 202: 2111-2120

Giguère L, Côté B, St-Pierre JF (1988) Metabolic rates scale isometrically in larval fishes. Mar Ecol Prog Ser 50:13-19 
Gillooly JF, Brown JH, West GB, Savage VM, Charnov EL (2001) Effects of size and temperature on metabolic rate. Science 293:2248-2251

Gillooly JF, Charnov EL, West GB, Savage VM, Brown JH (2002) Effects of size and temperature on developmental time. Nature 417:70-73

Gnaiger E (1983) Calculation of energetic and biochemical equivalents of respiratory oxygen consumption. In: Gnaiger E, Forstner H (eds) Polarographic oxygen sensors. Springer-Verlag, Berlin, p 337-345

Gnaiger E, Kemp RB (1990) Anaerobic metabolism in aerobic mammalian cells: information from the ratio of calorimetric heat flux and respirometric oxygen flux. Biochim Biophys Acta 1016:328-332

Goolish EM (1995) The metabolic implications of body size. In: Hochachka PW, Mommsen TP (eds) Biochemistry and molecular biology of fishes, Vol 4. Metabolic biochemistry. Elsevier Science, Amsterdam, p 335-366

Green EJ, Carritt DE (1967) New tables for oxygen saturation of seawater. J Mar Res 25:140-147

Gruber K, Weiser W (1983) Energetics of development of the Alpine charr, Salvelinus alpinus, in relation to temperature and oxygen. J Comp Physiol 149:485-493

Hemmingsen AM (1950) The relation of standard (basal) energy metabolism to total fresh weight of living organisms. Rep Steno Mem Hosp Nordisk Insulin Lab 4:7-58

Hemmingsen AM (1960) Energy metabolism as related to body size and respiratory surface, and its evolution. Rep Steno Mem Hosp Nordisk Insulin Lab 9:1-110

Heusner AA (1982) Energy metabolism and body size. I. Is the 0.75 mass exponent of Kleiber's equation a statistical artifact? Resp Physiol 48:1-12

Hughes GM (1984) Scaling of respiratory area in relation to oxygen consumption of vertebrates. Experimentia 40: $519-652$

Hughes GM, Al-Kadhomiy NK (1988) Changes in scaling of respiratory systems during the development of fishes. J Mar Biol Assoc UK 68:489-498

Hunt von Herbing I, Boutilier RG (1996) Activity and metabolism of larval Atlantic cod Gadus morhua from Scotian shelf and Newfoundland source populations. Mar Biol 124:607-617

Hunt von Herbing I, Boutilier RG, Miyake T, Hall BK (1996a) Effects of temperature on morphological landmarks critical to growth and survival in larval Atlantic cod (Gadus morhua). Mar Biol 124:593-606

Hunt von Herbing I, Miyake T, Hall BK, Boutilier RG (1996b) Ontogeny of feeding and respiration in larval Atlantic cod Gadus morhua (Teleostei, gadiformes). I. Morphology. J Morphol 227:15-35

Hunt von Herbing I, Miyake T, Hall BK, Boutilier RG (1996c) Ontogeny of feeding and respiration in larval Atlantic cod Gadus morhua (Teleostei, gadiformes). II. Function. J Morphol 227:37-50

Hunt von Herbing I, Gallager SM, Halteman W (2001) Metabolic costs of pursuit and attack in early larval Atlantic cod. Mar Ecol Prog Ser 216:201-212

Itazawa Y, Oikawa S (1983) Metabolic rates in exised tissues of carp. Experientia 39:160-161

Jobling M (1981) The influence of feeding on the metabolic rate of fishes: a short review. J Fish Biol 18:385-400

Jobling M (1994) Fish bioenergetics. Chapman \& Hall, London

Johnston IA, Guderley H, Franklin CE, Crockford T, Kamunde C (1994) Are mitochondria subject to evolutionary temperature adaptation? J Exp Biol 195:293-306

Kleiber M (1932) Body size and metabolism. Hilgardia 6: 315-353
Kleiber M (1975) The fire of life. An introduction to animal energetics. Robert E Krieger Publishing, Malabar, FL

Kurlansky M (1998) Cod. A biography of the fish that changed the world. Jonathon Cape, London

LaBarbera M (1989) Analyzing body size as a factor in ecology and evolution. Annu Rev Ecol Syst 20:97-117

Laurence GC (1973) Influence of temperature on energy utilization on embryonic and prolarval tautog, Tautoga onitis. J Fish Res Board Can 30:435-442

Laurence GC (1978) Comparative growth, respiration and delayed feeding abilities of larval cod (Gadus morhua) and haddock (Melanogrammus aeglefinus) as influenced by temperature during laboratory studies. Mar Biol 50:1-7

Laurence GC (1985) A report on the development of stochastic models of food limited growth and survival of cod and haddock larvae. In: Laurence GC, Lough RG (eds) Growth and survival of larval fishes in relation to trophodynamics of Georges Bank cod and haddock. NOAA Tech Memo NMFS-F/NEC-36 83-150

Laws EA, Archie JW (1981) Appropriate use of regression analysis in marine biology. Mar Biol 65:13-16

Liesing WA, Franks PJS (1999) Larval Atlantic cod (Gadus morhua) and haddock (Melanogrammus aeglefinus) growth on Georges bank: a model with temperature, prey size, and turbulence forcing. Can J Fish Aquat Sci 56: $25-36$

Liesing WA, Franks PJS (2000) Reply to Buckley et al.'s comment: 'Larval Atlantic cod and haddock growth models, metabolism, ingestion, and temperature effects'. Can J Fish Aquat Sci 57:1961-1963

Nelson JA, Tang Y, Boutilier RG (1996) The effects of salinity change on the exercise performance of two Atlantic cod (Gadus morhua) populations inhabiting different environments. J Exp Biol 199:1295-1309

Oikawa S, Itazawa Y (1983) Allometric relationship between tissue respiration and body mass in the carp. Comp Biochem Physiol 77A: 415-418

Oikawa S, Itazawa Y (1985) Gill and body surface areas of the carp in relation to body mass, with special reference to the metabolism-size relationship. J Exp Biol 117:1-14

Oikawa S, Itazawa Y (1993) Relationship between metabolic rate in vitro and body mass in a marine teleost, porgy $\mathrm{Pa}$ grus major. Fish Physiol Biochem 10:177-182

Otterlei E (2000) Temperature- and size-dependent growth of larval and early juvenile Atlantic cod (Gadus morhua L.). Dr scient thesis, University of Bergen

Otterlei E, Nyhammer G, Folkvord A, Stefansson SO (1999) Temperature- and size-dependent growth of larval and early juvenile Atlantic cod (Gadus morhua): a comparative study of Norwegian coastal cod and northeast Arctic cod. Can J Fish Aquat Sci 56:2099-2111

Overnell J, Batty RS (2000) Scaling of enzyme activity in larval herring and plaice: effects of temperature and individual growth rate on aerobic and anaerobic capacity. J Fish Biol 56:577-589

Packard GC, Boardman TJ (1988) The misuse of ratios, indices, and percentages in ecophysiological research. Physiol Zool 61:1-9

Peters RH (1983) The ecological implications of body size. Cambridge University Press, Cambridge

Pfeiler E (1996) Energetics of metamorphosis in bonefish (Albula sp.) leptocephali: role of keratan sulfate glycosaminoglycan. Fish Physiol Biochem 15:359-362

Pfeiler E, Govoni JJ (1993) Metabolic rates in early-life history stages of Elopomorph fishes. Biol Bull (Woods Hole) 185: $277-283$

Porter SM (2001) Effects of size and light on respiration and 
activity of walleye pollock (Theragra chalcogramma) larvae. J Exp Mar Biol Ecol 256:253-265

Post JR, Lee JA (1996) Metabolic ontogeny of teleost fishes. Can J Fish Aquat Sci 53:910-923

Reidy SP, Kerr SR, Nelson JA (2000) Aerobic and anaerobic swimming performance of individual Atlantic cod. J Exp Biol 203:347-357

Ricker WE (1958) Handbook of computations for biological statistics of fish populations. Bull Fish Res Board Can 119: $1-300$

Ricker WE (1973) Linear regressions in fisheries research. J Fish Res Board Can 30:409-434

Riisgård HU (1998) No foundation of a '3/4 power scaling law' for respiration in biology. Ecol Lett 1:71-73

Rohlf FJ, Sokal RR (1995) Statistical tables. WH Freeman \& Co, New York

Rombough PJ (1988) Respiratory gas exchange, aerobic metabolism, and effects of hypoxia during early life. In: Hoar WS, Randall DJ (eds) Fish physiology, Vol XI. The physiology of developing fish. Part A. Eggs and larvae. Academic Press, NY, p 59-161

Rombough PJ (1994) Energy partitioning during fish development: additive or compensatory of energy to support growth? Funct Ecol 8:178-186

Rombough PJ (1998) Partitioning of oxygen uptake between the gills and skin in fish larvae: a novel method for estimating cutaneous oxygen uptake. J Exp Biol 201: 1763-1769

Rombough PJ, Moroz BM (1997) The scaling and potential importance of cutaneous and branchial surfaces in respiratory gas exchange in larval and juvenile walleye Stizostedion vitreum. J Exp Biol 200:2459-2468

Rønnestad I, Naas KE (1993) Oxygen consumption and ammonia excretion in larval Atlantic halibut (Hippoglossus hippoglossus) at first feeding: a first step towards an energetic model. In: Walther BT, Fyhn HJ (eds) Physiological and biochemical aspects of fish development. University of Bergen, p 279-284

Saunders RL (1963) Respiration of the Atlantic cod. J Fish Res Board Can 20:373-386

Schmidt-Nielsen K (1984) Scaling. Why is animal size is so important? Cambridge University Press, Cambridge

Schurmann H, Steffensen JF (1992) Lethal oxygen levels at different temperatures and the preferred temperature during hypoxia of the Atlantic cod, Gadus morhua L. J Fish Biol 41:927-934

Schurmann H, Steffensen JF (1994) Spontaneous swimming activity of Atlantic cod Gadus morhua exposed to graded hypoxia at three temperatures. J Exp Biol 197:129-142

Schurmann H, Steffensen JF (1997) Effects of temperature, hypoxia and activity on the metabolism of juvenile Atlantic cod. J Fish Biol 50:1166-1180

Scott WB, Scott MG (1988) Atlantic fishes of Canada. Can Bull Fish Aquat Sci 219

Segner H, Storch V, Reinecke M, Klaos W, Hanke W (1994) The development of functional digestive and metabolic organs in turbot, Scophthalmus maximus. Mar Biol 119: $471-486$

Serigstad B (1986) Effects of oil on the physiology and development of fish larvae, respiratory studies. In: Fyhn HJ (ed) Fish larval physiology and anatomy. Basic research and effects of oil. University of Bergen, p 203-251

Serigstad B (1987a) Respiratory studies on cod (Gadus morhua L.) with special reference to effects of oil exposure on eggs and larvae. Dr scient thesis University of Bergen

Serigstad B (1987b) Oxygen uptake of developing fish eggs and larvae. Sarsia 72:369-371
Skiftesvik AB (1992) Changes in behaviour at onset of exogenous feeding in marine fish larvae. Can J Fish Aquat Sci 49:1570-1572

Sokal RR, Rohlf FJ (2000) Biometry. WH Freeman \& Co, New York

Solberg T, Tilseth S (1984) Growth, energy consumption and prey density requirements in first feeding larvae of cod (Gadus morhua L.). In: Dahl E, Danielssen DS, Moksness E, Solemdal P (eds) The propagation of cod (Gadus morhua L.), Vol 1. Institute of Marine Research, Flødevigen Biological Station, Arendal, p 145-166

Solberg TS, Tilseth S (1987) Variations in growth patterns among yolk-sac larvae of cod (Gadus morhua L.) due to differences in rearing temperature and light regime. Sarsia 72:347-349

Soofiani NM, Hawkins AD (1982) Energetic costs at different levels of feeding in juvenile cod, Gadus morhua L. J Fish Biol 21:577-592

Soofiani NM, Priede IG (1985) Aerobic metabolic scope and swimming performance in juvenile cod, Gadus morhua L. J Fish Biol 26:127-138

Steffensen JF, Schurmann H, Bushnell PG (1994) Oxygen consumption in 4 species of teleosts from Greenland-no evidence of metabolic cold adaptation. Polar Biol 14:49-54

Sundnes G (1957) Notes on the energy metabolism of the cod (Gadus callarias L.) and the coalfish (Gadus virens L.) in relation to body size. Fiskeridir Skrift Ser Havunders XI: $2-10$

Tang Y, Nelson JA, Reidy SP, Kerr SR, Boutilier RG (1994) A reappraisal of activity metabolism in Atlantic cod (Gadus morhua). J Fish Biol 44:1-10

Terjesen BF, Finn RN, Norberg B, Rønnestad I (2002) Kinetics and fates of ammonia, urea, and uric acid during oocyte maturation and ontogeny of the Atlantic halibut (Hippoglossus hippoglossus L.). Comp Biochem Physiol 131A: 443-455

Torres JJ, Brightman RI, Donnelly J, Harvey J (1996) Energetics of larval red drum, Sciaenops ocellatus. Part I: Oxygen consumption, specific dynamic action, and nitrogen excretion. Fish Bull 94:756-765

Utne-Palm AC, Stiansen JE (2002) Effect of larval ontogeny, turbulence and light on prey attack rate and swimming activity in herring larvae. J Exp Mar Biol Ecol 268:147-170

van der Meeren T, Jørstad KE (2001) Growth and survival of Arcto-Norwegian and Norwegian coastal cod larvae (Gadus morhua L.) reared together in mesocosms under different light regimes. Aquacult Res 32:549-563

van der Meeren T, Jørstad KE, Solemdal P, Kjesbu OS (1994) Growth and survival of cod larvae (Gadus morhua L.): comparative enclosure studies of Northeast Artic cod and coastal cod from Western Norway. ICES Mar Sci Symp 198:633-645

Vigrestad A (1993) Effect of oil exposure on the metabolic rate of embryonic Atlantic cod (Gadus morhua L.) at different temperatures. Cand scient thesis, University of Bergen

Wells PR, Pinder AW (1996a) The respiratory development of Atlantic salmon I. Morphometry of gills, yolk sac and body surface. J Exp Biol 199:2725-2736

Wells PR, Pinder AW (1996b) The respiratory development of Atlantic salmon II. Partitioning of oxygen uptake among gills, yolk sac and body surfaces. J Exp Biol 199:2737-2744

West GB, Brown JH, Enquist BJ (1997) A general model for the origin of allometric scaling laws in biology. Science 276:122-126

West GB, Brown JH, Enquist BJ (1999) A general model for the structure of plant vascular systems. Nature 400:664-667

West GB, Brown JH, Enquist BJ (2001) A general model for ontogenetic growth. Nature 413:528-631 
West GB, Woodruff WH, Brown JH (2002) Allometric scaling of metabolic rate from molecules and mitochondria to cells and mammals. Proc Nat Acad Sci USA 99:2473-2478

Wieser W (1984) A distinction must be made between the ontogeny and phylogeny of metabolism in order to understand the mass exponent of energy metabolism. Resp Physiol 55:1-9

Wieser W (1991) Limitations of energy aquisition and energy use in small poikilotherms: evolutionary implications. Func Ecol 5:234-240

Wieser W (1995) Review article: energetics of fish larvae, the smallest vertebrates. Acta Physiol Scand 154:279-290

Wieser W, Forstner H (1986) Effects of temperature and size on the routine rate of oxygen consumption and on the relative scope for activity in larval cyprinids. J Comp Physiol B 156:791-796

Editorial responsibility: Howard Browman (Contributing Editor), Storebø, Norway
Winberg GG (1956) Rate of metabolism and food requirements of fishes. Fish Res Board Can Transl Ser (1960) 194: $1-265$

Witting L (1998) Body mass allometries caused by physiological or ecological constraints. Trends Ecol Evol 13:25

Wood CM (2001) Influence of feeding, exercise, and temperature on nitrogen metabolism and excretion. In: Wright PA, Anderson PM (eds) Nitrogen excretion. Academic Press, London, p 201-238

Wright PA, Fyhn HJ (2001) Ontogeny of nitrogen metabolism and excretion. In: Wright PA, Anderson PM (eds) Nitrogen excretion. Academic Press, London, p 149-200

Zeuthen E (1953) Oxygen uptake as related to body size in organisms. Q Rev Biol 28:1-12

Zeuthen E (1970) Rate of living as related to body size in organisms. Pol Arch Hydrobiol 17:21-30

Submitted: February 26, 2002; Accepted: June 21, 2002

Proofs received from author(s): October 16, 2002 